University of Nebraska - Lincoln

DigitalCommons@University of Nebraska - Lincoln

Resistance evolution to the first generation of genetically modified Diabrotica-active Bt-maize events by western corn rootworm: management and monitoring considerations

\author{
Yann Devos \\ European Food Safety Authority, yann.devos@efsa.europa.eu \\ Lisa N. Meihls \\ USDA-NIFA \\ Jozsef Kiss \\ Szent Istvan University \\ Bruce E. Hibbard \\ University of Missouri, bruce.hibbard@ars.usda.gov
}

Follow this and additional works at: https://digitalcommons.unl.edu/usdaarsfacpub

Devos, Yann; Meihls, Lisa N.; Kiss, Jozsef; and Hibbard, Bruce E., "Resistance evolution to the first generation of genetically modified Diabrotica-active Bt-maize events by western corn rootworm: management and monitoring considerations" (2013). Publications from USDA-ARS / UNL Faculty. 1242. https://digitalcommons.unl.edu/usdaarsfacpub/1242

This Article is brought to you for free and open access by the U.S. Department of Agriculture: Agricultural Research Service, Lincoln, Nebraska at DigitalCommons@University of Nebraska - Lincoln. It has been accepted for inclusion in Publications from USDA-ARS / UNL Faculty by an authorized administrator of DigitalCommons@University of Nebraska - Lincoln. 


\title{
Resistance evolution to the first generation of genetically modified Diabrotica-active $B t$-maize events by western corn rootworm: management and monitoring considerations
}

\author{
Yann Devos • Lisa N. Meihls · József Kiss • \\ Bruce E. Hibbard
}

Received: 6 May 2012/ Accepted: 7 September 2012/Published online: 26 September 2012

(C) Springer Science+Business Media Dordrecht 2012

This article is a U.S. government work, and is not subject to copyright in the United States.

\begin{abstract}
Western corn rootworm (Diabrotica virgifera virgifera; WCR) is a major coleopteran maize pest in North America and the EU, and has traditionally been managed through crop rotation and broad-spectrum soil insecticides. Genetically modified $B t$-maize offers an additional management tool for WCR and has been valuable in reducing insecticide use and increasing farm income. A concern is that the widespread, repeated, and exclusive deployment of the same $B t$-maize transformation event will result in the rapid
\end{abstract}

Disclaimer: Opinions and views (if any) expressed in this publication do not necessarily reflect those of the European Food Safety Authority (EFSA). This publication does not disclose any confidential information or data. Mention of proprietary products is solely for the purpose of providing specific information, and does not constitute an endorsement or a recommendation by EFSA or USDA-ARS for their use.

Y. Devos $(\square)$

European Food Safety Authority, GMO Unit, Via Carlo Magno 1, 43126 Parma, Italy

e-mail: Yann.Devos@efsa.europa.eu

\section{N. Meihls}

USDA-NIFA, The Boyce Thompson Institute for Plant Research, Tower Road, Ithaca, NY 14853-1801, USA

J. Kiss

Plant Protection Institute, Szent István University, Pater Károly 1, 2100 Gödöllő, Hungary

B. E. Hibbard

USDA-ARS, Plant Genetics Research Unit, University of Missouri, 205 Curtis Hall, Columbia, MO 65211, USA evolution of resistance in WCR. This publication explores the potential of WCR to evolve resistance to plant-produced $B t$-toxins from the first generation of Diabrotica-active Bt-maize events (MON 863 and MON 88017, DAS-59122-7 and MIR604), and whether currently implemented risk management strategies to delay and monitor resistance evolution are appropriate. In twelve of the twelve artificial selection experiments reported, resistant WCR populations were yielded rapidly. Field-selected resistance of WCR to Cry3Bb1 is documented in some US maize growing areas, where an increasing number of cases of unexpected damage of WCR larvae to $B t$-maize MON 88017 has been reported. Currently implemented insect resistance management measures for $B t$-crops usually rely on the high dose/refuge (HDR) strategy. Evidence (including laboratory, greenhouse and field data) indicates that several conditions contributing to the success of the HDR strategy may not be met for the first generation of $B t$-maize events and WCR: (1) the $B t$-toxins are expressed heterogeneously at a low-tomoderate dose in roots; (2) resistance alleles may be present at a higher frequency than initially assumed; (3) WCR may mate in a non-random manner; (4) resistance traits could have non-recessive inheritance; and (5) fitness costs may not necessarily be associated with resistance evolution. However, caution must be exercised when extrapolating laboratory and greenhouse results to field conditions. Model predictions suggest that a $20 \%$ refuge of non-Diabrotica-active $B t$-maize can delay resistance evolution in WCR under 
certain conditions. This publication concludes that further research is needed to resolve the remaining scientific uncertainty related to the appropriateness of the HDR in delaying resistance evolution in WCR, resistance monitoring is essential to detect early warning signs indicating resistance evolution in the field, and that integrated pest management reliant on multiple tactics should be deployed to ensure effective long-term corn rootworm management and sustainable use of $B t$-maize.

Keywords Bt-toxins $\cdot$ Compliance $\cdot$ Genetically modified maize $\cdot$ Resistance evolution $\cdot$ Resistance management $\cdot$ Resistance monitoring $\cdot$ Seed blends . Western corn rootworm

\section{Introduction}

Western corn rootworm (Diabrotica virgifera virgifera; WCR; Fig. 1) (Coleoptera: Chrysomelidae) is a major coleopteran maize pest and a serious threat to agriculture in North America (Metcalf 1986; Dun et al. 2010; Tinsley et al. 2012) and the European Union (EU) (FCEC 2009; Wesseler and Fall 2010). WCR overwinters through eggs that are laid during midsummer till autumn, mainly in maize fields. Larvae hatching in the following spring feed on fine maize root hairs, where they typically burrow into root tips of maize seedlings. As the larvae grow larger, they move, feed and tunnel into younger nodes of adventitious roots of the nodal root system (Meinke et al. 2009), and negatively affect yield by decreasing nutrient and water uptake and plant stability. Maize plants suffering from moderate to severe root pruning are susceptible to lodging, which can result in additional yield losses due to difficulties in harvesting lodged plants (Levine and Oloumi-Sadeghi 1991). The bulk of plant damage is caused by second and third instars, but adults feeding on silk and grains can be damaging in seed and sweet corn production (Tuska et al. 2002). WCR has been introduced to the EU from North America (Miller et al. 2005), where it is native and widespread. It was first detected near Belgrade (Serbia) in 1992, but has since spread across the continent (Hummel 2003; Kiss et al. 2005a; Boriani et al. 2006; Ciosi et al. 2008; Gray et al. 2009; Meinke et al. 2009), resulting in well-established populations in approximately 19 European countries (EC 2012; http://extension.entm.purdue.edu/wcr/). It is expected that this invasive pest species will expand further in the EU (Hemerik et al. 2004; Moeser and Vidal 2005; Ciosi et al. 2011; Aragón and Lobo 2012).

Pest management options for WCR are usually directed towards larval feeding and consist of crop rotation, the use of maize seed coated with systemic insecticides and the application of soil insecticides (applied at planting) (Levine and Oloumi-Sadeghi 1991; Széll et al. 2005; Boriani et al. 2006; Ma et al. 2009; van Rozen and Ester 2010; Meissle et al. 2011b). Crop rotation is highly effective in controlling WCR, as females lay their eggs mainly in maize fields and the larvae hatching in the following year do not survive well on other crop roots (Levine and OloumiSadeghi 1991; Kiss et al. 2005b, Boriani et al. 2006; Meissle et al. 2011b). Foliar broad-spectrum insecticides are sometimes applied to suppress adult populations, especially in continuous maize, in order to decrease egg-laying by adult females and hence the number of overwintering eggs and hatching larvae in the following year (Levine and Oloumi-Sadeghi 1991; Boriani et al. 2006). Foliar insecticides can also be applied to prevent silk clipping by adults in seed and sweet corn production, where high grain quality is essential for marketing (Levine and Oloumi-Sadeghi 1991; Tuska et al. 2002; Boriani et al. 2006; van Rozen and Ester 2010; Meissle et al. 2011b). However, the behavioural and genetic plasticity of WCR has made the long-term viability of many of these pest management options uncertain (Levine and Oloumi-Sadeghi 1991; Onstad 2008; Miller et al. 2009), especially in the USA. In a growing portion of maize growing areas of the USA, a crop rotation-resistant WCR variant evolved where females have adapted their egg-laying behaviour to lay eggs in crops other than maize, leading to damage in first-year maize in spite of crop rotation (Levine and Oloumi-Sadeghi 1996; Levine et al. 2002; Gray et al. 2009). Such a crop rotationresistant WCR variant has not evolved in the EU yet. Further, WCR has evolved resistance to broadcast cyclodiene insecticides used for larval control in the 1950s and early 1960s (Ball and Weekman 1962) and broadcast insecticides used for beetle management in the USA (Meinke et al. 1998; Wright et al. 2000; Siegfried et al. 2004). In contrast, resistance has not evolved to granular soil insecticides applied in a narrow band over the row, despite more than 50 years of usage of the same insecticidal mode of action. 

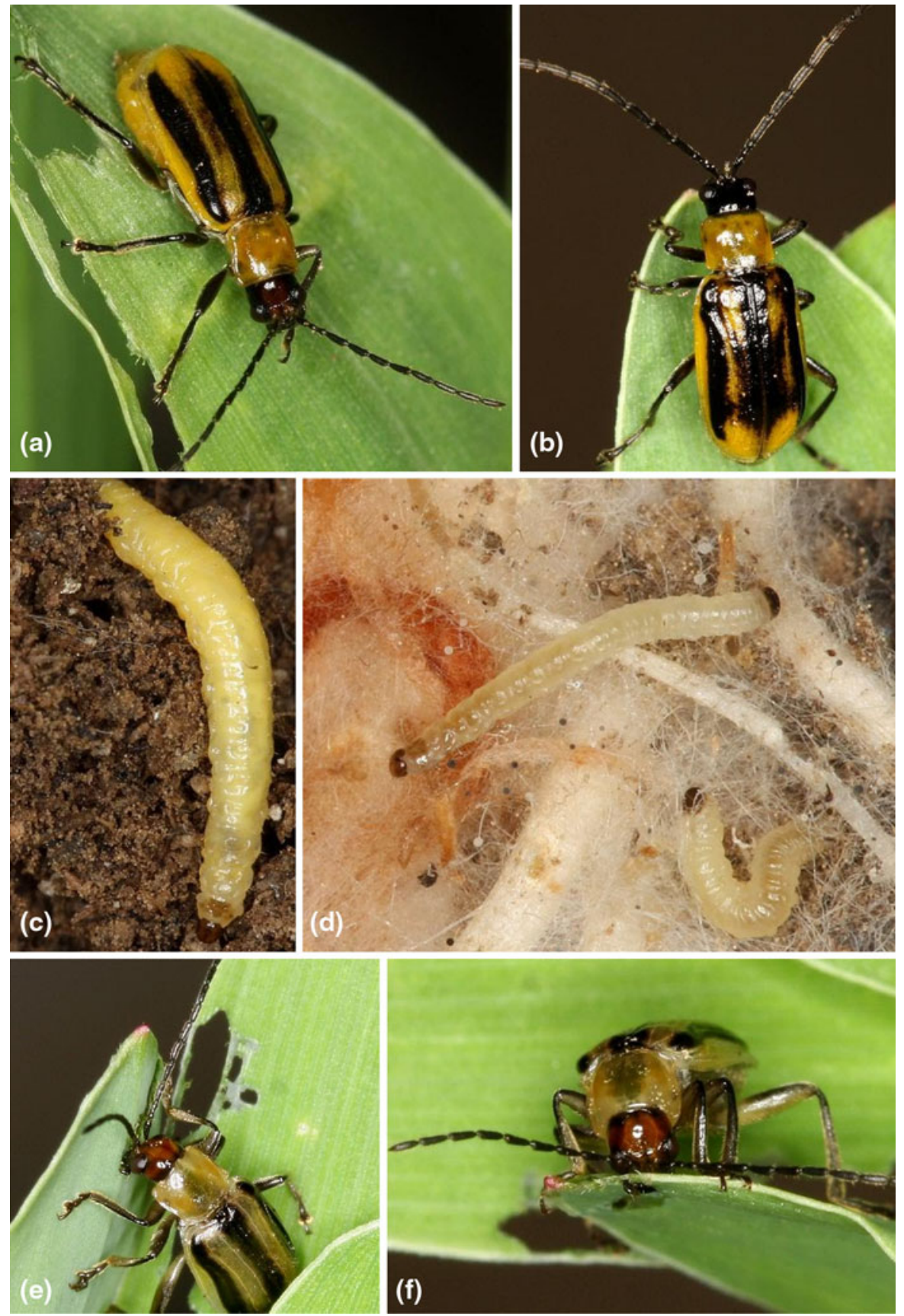

Fig. 1 (a) Female western corn rootworm (WCR), (b) male WCR, (c) third instar larva of WCR, (d) WCR larva feeding on maize roots, (e-f) adult WCR feeding on a maize leaf. Photos by Anthony Zukoff and reprinted with permission

In EU regions where WCR populations have been detected (EC 2012), but are not yet established, mandatory eradication programs require the application of insecticides and planting restrictions of maize in buffer zones surrounding new introduction points (Carrasco et al. 2009; FCEC 2009).

Genetically modified (GM) maize transformation events expressing insecticidal Bacillus thuringiensis 
$(B t)$ toxins (such as three domain-like Cry3, binary- or hybrid-like toxins; see Crickmore et al. 2012 for the $B t$-toxin nomenclature) against corn rootworms offer an additional means of control against WCR. The mode of action of $B t$-toxins is to bind selectively to specific receptors on the epithelial surface of the midgut of larvae of susceptible insect species, leading to death of larvae through pore formation, cell burst and subsequently septicemia (reviewed by OECD 2007; Sanahuja et al. 2011; Bravo et al. 2012; Vachon et al. 2012). Several Diabrotica-active Bt-maize events are currently grown commercially in Argentina, Brazil, Canada and the USA (Table 1). Depending on the region, Diabrotica-active $B t$-maize is used to control chrysomelid beetles such as the western (D. v. virgifera), northern (Diabrotica barberi) and mexican corn rootworm (D. v. zea), and Diabrotica speciosa. At present, WCR is the only species from the corn rootworm complex present in the EU. The European authority responsible for providing advice on the safety of GM plants at EU level (European Food Safety Authority, EFSA) recently issued its first scientific opinion on the cultivation of a Diabroticaactive $B t$-maize (EFSA 2011c). This scientific opinion has been passed to the European Commission and EU Member States, and it now lies within the decisionmaking process to decide whether this $B t$-maize can be authorised for cultivation in the EU (Raybould and Poppy 2012).

Compared with pest management currently practiced against WCR in conventional maize cropping systems, cultivation of Diabrotica-active Bt-maize can reduce the use of insecticides that are more harmful to the environment, given that less or no treatments with soil or foliar broad-spectrum insecticides may be needed (Porter et al. 2012). However, there is a concern that the widespread, repeated, and exclusive use of $B t$-maize expressing the same $B t$-toxin by individual farmers as the sole pest management option against WCR will create significant selection pressure and increase the risk of WCR evolving resistance (Siegfried et al. 1998). Resistance is practically defined in this publication as significant crop damage (product failure) caused primarily by a heritable reduction in susceptibility of the target insect pest population to the $B t$-toxin after exposure to the toxin (see Head and Greenplate 2012). Susceptibility of target insect pests to plant-produced $B t$-toxins is viewed in some jurisdictions as a common good that should be preserved (Glaser and Matten 2003; Bourguet et al. 2005; Gassmann and Hutchison 2012) due to the benefits of Bt-crops (e.g., Qaim 2009; Carpenter 2010; Hutchison et al. 2010; Areal et al. 2012; Lu et al. 2012; Wan et al. 2012) and the broader use of sprayable $B t$-formulations. Resistance evolution in target insect pests is not considered a direct environmental harm, but the consequences of the establishment of resistant populations may lead to altered pest management practices. Depending upon the level of resistance, resistant populations would reduce the efficacy of $B t$-maize to control the insect pests it targets. Therefore, farmers may have to revert back to the currently used pest management tools that have a higher environmental impact, and to displace biocontrol programs at a larger scale, or have to alter their cultivation/farming system (i.e., rotate maize with other crops), which may decrease farm income (Andow 2008).

This publication reviews current data in terms of laboratory-, greenhouse- and field-selected resistance in WCR to plant-produced $B t$-toxins from $B t$-maize events targeting this pest. More specifically, we explore: (1) whether resistance to $B t$-toxins in WCR has been observed under artificial and field conditions; (2) whether insect resistance management (IRM) measures currently implemented for Bt-crops will adequately and efficiently delay resistance evolution in WCR; and (3) what monitoring strategies can be followed to detect early warning signs indicating resistance evolution in the field after $B t$-crops have been placed on the market. Even though several stacked Diabrotica-active Bt-maize events—a stack combines non-related traits such as herbicide tolerance and insect resistance against other target insect pests - are cultivated in Argentina, Canada and the USA and are in the approval pipeline in the EU (Table 1), we focus here on the first generation of Diabrotica-active $B t$-maize events, covering: the Cry3Bb1-expressing Bt-maize events MON 863 and MON 88017; the Cry34Ab1/Cry35Ab1-expressing $B t$-maize event DAS-59122-7; and the mCry3Aexpressing $B t$-maize event MIR604 (referred to hereafter as Bt-maize MON 863 and MON 88017, DAS59122-7 and MIR604, respectively). 







\section{Resistance evolution of WCR to Diabrotica-active Bt-maize}

Laboratory- and greenhouse-selected resistance

In artificial laboratory and greenhouse selection experiments, the evolution of resistance to Cry3Bb1, Cry34Ab1/Cry35Ab1 and mCry3A against WCR has been demonstrated for $B t$-maize MON 863 and MON 88017, DAS-59122-7 and MIR604.

Meihls et al. (2008) exposed WCR colonies to Btmaize MON 863 in the greenhouse under different selection regimes. After three and six generations of selection, the colony that was continuously exposed to $B t$-maize (larvae were reared on $B t$-maize throughout the entire larval development period) was resistant; larval survival on $B t$-maize was equivalent to survival on the near-isogenic line. After three generations of selection, the $\mathrm{LC}_{50}$ (toxin concentration causing $50 \%$ mortality) of the continuously exposed colony was approximately 22-fold greater than that of the unexposed control colony reared on the near-isogenic line. After six generations of selection, percent survival on Bt-maize relative to its near-isogenic line was twelvefold greater in the field for the continuously exposed colony than for the control colony. In their laboratory selection experiments with WCR colonies reared on Bt-maize MON 863, Oswald et al. (2011) reported that survivorship to adult stage (emergence) on $B t$-maize MON 863 was approximately four times greater for both the moderate (exposed over eleven generations) and intense selected lines (exposed over seven generations) than for controls. Average rates of emergence increased sixfold over the final six generations in the moderate selected colony and approximately threefold over the final four generations in the intense selected colony. The realised heritability $\left[h^{2}=\right.$ the ratio of the response to selection (R) to the selection differential $(\mathrm{S})$ ] of resistance for the moderate and intense selected colonies was estimated to be 0.16 and 0.15 , respectively, indicating that genetic variation accounted for only a small proportion of the resistance compared with environmental variation (Oswald et al. 2011). Meihls (2010) made similar observations for $B t$-maize MON 88017, and reported that larval survival was equivalent on $B t$-maize and the near-isogenic line for three selected colonies following three generations of selection on $B t$-maize in the greenhouse, but not for the control colonies. 
Resistance evolution in two WCR colonies reared on Bt-maize DAS-59122-7 seedlings was observed over eleven generations of selection (Lefko et al. 2008). An increased WCR survivorship from the first generation to the ninth generation of 15- and 59-fold was found for the two WCR colonies that were selected to survive on Bt-maize DAS-59122-7. While resistance levels increased over the generations of selection, they fluctuated considerably for the initial four to six generations, but resistance remained stable after five to seven generations with a survival that was at least ten times greater than that observed during the first generation of selection. After one and six generations of selection, the mean population fitness (number of adults divided by number of hatched eggs) was approximately 0.03 and 1.00 , respectively. After ten and eleven generations of selection on $B t$-maize DAS-59122-7 with no random mating, the estimated $h^{2}$ values declined from 0.29 to 0.11 , suggesting that Lefko et al. (2008) failed to fix resistance in the two WCR colonies under realistic exposure.

For Bt-maize MIR604 significant increases in $\mathrm{mCry} 3 \mathrm{~A}$ resistance ratios, which are calculated as the $\mathrm{LC}_{50}$ value of the selected colony divided by the $\mathrm{LC}_{50}$ value of the susceptible colony, with both colonies tested under the same conditions, were seen after seven and ten generations of selection (fourfold and 15-fold, respectively) in toxicity bioassays. When the selected and control colonies were evaluated in the field, control colony larvae caused significantly more damage to the near-isogenic line than $B t$-maize MIR604, but damage to Bt-maize MIR604 and the near-isogenic line was not significantly different for the selected WCR colony. After four and seven generations of selection, survival of the selected colony was similar on $B t$-maize mCry $3 \mathrm{~A}$ and the near-isogenic line in the greenhouse and field, respectively (Meihls et al. 2011).

In all cases described above, resistance to Cry3Bb1, Cry34Ab1/Cry35Ab1 and mCry3A evolved in a relatively short time (in as few as three generations with no random mating), and resistance was found to remain at a similar level after six generations of selection. The expression of $B t$-toxins in $B t$-maize MON 863 and MON 88017, DAS-59122-7 and MIR604 is low-to-moderate and some susceptible WCR individuals survive on $B t$-maize (see " $B t$-toxin is expressed at appropriate levels in relevant plant parts"). Therefore, resistance ratios could not be high (e.g., 5-22) (Meihls et al. 2008, 2011). These values are overall at least an order of magnitude lower than those found for some Cry resistant Lepidoptera (Tabashnik et al. 2009; Siegfried and Hellmich 2012), but can substantially enhance survival on $B t$-maize (Gassmann et al. 2012). Laboratory- or greenhouse-selected WCR colonies with Cry3Bb1 and $\mathrm{mCry} 3 \mathrm{~A}$ resistance have been shown to have increased resistance under field conditions (Meihls et al. 2008, 2011; Meihls 2010), indicating that larval survival on $B t$-maize plants in the greenhouse translated to larval survival on $B t$-maize in the field. Survival on transgenic plants remained high, despite the fact that the resistance ratio in diet bioassays declined to less than fivefold by the sixth generation (compared with 22-fold by the third generation) (Meihls et al. 2008). Lefko et al. (2008) did not evaluate their selected populations in the field, but assessed damage to $B t$-maize DAS-59122-7 from two selected WCR populations under greenhouse conditions. Damage caused by WCR was shown to increase gradually with repeated generations of selection on $B t$-maize relative to that caused by WCR from the first generation of selection, but overall damage remained low. The similar estimated $h^{2}$ values for WCR resistance to Cry3Bb1 and Cry34Ab1/Cry35Ab1 suggest that the risk of resistance evolution is similar for both toxins (Tabashnik and Gould 2012).

\section{Field-selected resistance}

Field-selected resistance of WCR to Cry3Bb1 is documented in some US maize growing areas (Gassmann et al. 2011, 2012), and an increasing number of cases of unexpected WCR damage to Cry3Bb1expressing Bt-maize has been reported since 2009 (reviewed in US EPA 2011a). These control failure reports are indicative of an increased Cry3Bb1 tolerance in WCR. Gassmann et al. (2011) demonstrated that fields identified by farmers as having severe WCR feeding damage to Cry3Bb1-expressing Bt-maize (problem fields) in Iowa in 2009 contained WCR populations that displayed three times greater survival on Bt-maize MON 88017 seedlings in laboratory bioassays than did WCR from fields where such damage was not reported (control fields): mean survival on $B t$-maize of larvae from problem and control fields was 52 and $17 \%$, respectively. In contrast, larval survival on non-Bt-maize was similar 
for both problem and control fields (Gassmann et al. 2011). Further, the observed response has been shown to have a heritable component. Subsequent field experiments in two of the 2009 problem fields found no difference in survival of WCR between Cry3Bb1expressing maize and non-Bt-maize, and higher root damage to $B t$-maize MON 88017 than any other treatment tested, except maize that had no protection against larval WCR (Gassmann 2012). In a follow-up study, Gassmann et al. (2012) revealed that WCR populations sampled from problem fields in 2010 had a survival and development on Bt-maize MON 88017 seedlings that was eleven times higher and significantly faster than that of control populations, respectively. Multiple and increased performance failures of Bt-maize MON 88017 were also reported during the 2011 maize growing season in Illinois, Minnesota, Nebraska and South Dakota (Gray 2011a, b, c; US EPA 2011a; Porter et al. 2012).

Gassmann et al. (2011, 2012) found a significant positive correlation between the number of years that $B t$-maize MON 88017 had been grown in a field and the survival of WCR populations on $B t$-maize MON 88017 seedlings in laboratory bioassays. In 2009 , corrected survival of WCR ranged between 17 and $21 \%$ for populations from control fields (no history of Bt-maize MON 88017 cultivation), and between 32 and $62 \%$ for populations from problem fields where $B t$-maize MON 88017 had been grown for at least three consecutive years (Gassmann et al. 2011), corresponding to at least three generations of selection (Meihls et al. 2008; Gray et al. 2009). The problem fields in Illinois during the 2011 maize growing season were also planted to $B t$-maize MON 88017 for many successive years without crop rotation (Gray 2011a, b).

Given that resistance has evolved in nine of the nine artificial laboratory and greenhouse selection experiments conducted with Cry3Bb1-expressing Bt-maize within just a few generations (Meihls et al. 2008, Meihls 2010, Oswald et al. 2011), it is not surprising resistance evolved under field conditions after three to seven generations of selection (Gassmann et al. 2011, 2012). Cry3Bb1-expressing Bt-maize was first to market and has been the dominant Diabrotica-active $B t$-maize event, with the area planted in the USA increasing from 0.2 million ha in 2003 to 12.8 million ha in 2009 (Monsanto 2009). The first approval for commercial cultivation for Bt-maize DAS-59122-7 and MIR604 in the USA was in 2005 and 2006, respectively, resulting in a lower market share compared with Cry3Bb1-expressing Bt-maize. Since resistance to Cry34Ab1/Cry35Ab1 (Lefko et al. 2008) and mCry3A (Meihls et al. 2011) also evolved relatively quickly under laboratory and/or greenhouse settings, field-selected resistance to Bt-maize DAS-59122-7 and MIR604 is possible too and therefore vigilance should be exercised. Tabashnik and Gould (2012) attributed the lack of reported field-selected resistance to Cry34Ab1/Cry35Ab1 and mCry3A so far to the lower exposure of WCR populations to these toxins, rather than an inherently lower risk of evolving resistance compared with Cry3Bb1. Based on the available data, it can be concluded that WCR has the ability to evolve resistance to Cry3Bb1, Cry34Ab1/ Cry35Ab1 and mCry3A relatively rapidly, especially if the same $B t$-maize is used continuously for three to five growing seasons, and the WCR infestation levels are high. It is therefore advisable that farmers who grow Bt-maize MON 88017, DAS-59122-7 or MIR604 put appropriate risk mitigation measures in place to delay resistance evolution.

\section{Resistance management}

High dose/refuge strategy

As part of the GMO approval process, applicants (also named registrants) submitting an application for cultivation of $B t$-crops proactively provide an IRM plan. IRM plans are designed to minimise the selection pressure associated with $B t$-crops, in order to prevent or at least delay resistance evolution in the target insect pests and to extend the durability of $B t$-crops (Bates et al. 2005; Alcalde et al. 2007; Andow 2008; MacIntosh 2010; Head and Greenplate 2012). As currently implemented for several Bt-crops in several countries, IRM plans usually rely on the HDR strategy (Gould 1998; Glaser and Matten 2003; MacIntosh 2010). The HDR strategy proscribes planting $B t$-crops that produce a very high concentration of the $B t$-toxin (25 times the amount needed to kill $>99 \%$ of susceptible individuals $\left[\mathrm{LC}_{99}\right]$ ), so that nearly all target insect pests that are heterozygous for resistance do not survive on it. In addition, a nearby structured refuge of the non-Bt-crop is required where the target insect pest does not encounter the $B t$-toxin 
(Alstad and Andow 1995; Gould 1998; Ives and Andow 2002). Note that non-Bt-crops or refuges are intended to mean areas with the crop that does not express $B t$-toxins which are active against the target insect pest. Under these conditions, most of the rare resistant individuals surviving on the $B t$-crop will mate with abundant susceptible individuals emerging from nearby refuges to produce heterozygous offspring that are phenotypically susceptible. If inheritance of resistance is recessive, then the hybrid progeny from such matings will die on the $B t$-crop.

Success of the HDR strategy is aided if the following conditions are met: (1) the Bt-toxin is expressed at appropriate levels in relevant plant parts; (2) initial resistance alleles are rare in the target insect pest population, so that nearly all resistance alleles will be in heterozygote individuals that cannot survive on the Bt-crop; (3) random mating occurs between resistant insects emerging in $B t$-crops and susceptible insects preserved on refuges at sufficient levels; (4) resistance alleles are partially or fully recessive; and (5) fitness costs are associated with the resistance. Whether these conditions of the HDR strategy are met for WCR and Bt-maize MON 863 and MON 88017, DAS-59122-7 and MIR604 is considered below.

\section{Bt-toxin is expressed at appropriate levels in relevant plant parts}

The predicted duration of susceptibility of target insect pests to the $B t$-toxin is dependent upon many factors (e.g., Tyutyunov et al. 2008), including its dose in the $B t$-crop (Onstad et al. 2001a). It is generally assumed that the $B t$-toxin concentration in relevant plant parts must be sufficiently high to kill a high proportion of heterozygous resistant genotypes, so that any resistance allele in the target insect pest population remains functionally recessive (Gould 1998; Andow 2008). Instances of field-selected resistance reported so far (reviewed by Tabashnik et al. 2009; Huang et al. 2011) support model predictions that target insect pests are at greater risk of evolving resistance if managed by $B t$-crops that are not high dose (Tabashnik et al. 2004).

The average reduction in WCR emergence from $B t$-maize MON 863 reported by Clark et al. (2012) relative to that from the near-isogenic line was $98.49 \%$, when averaged across all the environments tested. In data provided to US Environmental Protection Agency (US EPA), the applicant reported WCR mortality due to $B t$-maize MON 88017 of $97.5 \%$ (US EPA 2010a). In the case of $B t$-maize MON 863, Meihls et al. (2008) yielded a mortality estimate of $96.21 \%$. Siegfried et al. (2005) and others (Nowatzki et al. 2006; Meissle et al. 2011a) characterised WCR as not extremely sensitive to Cry3Bb1.

The average reduction in adult WCR emergence on Bt-maize DAS-59122-7 across three environments was $96.48 \%$ (Storer et al. 2006; see also Hibbard et al. 2010a). Storer et al. (2006) stated relative mortality rates in field studies comparing $B t$-maize DAS-591227 plots to non- $B t$-maize plots averaged $99.62 \%$ after adjusting for density-dependent mortality. With mechanically infested plots at the infestation levels used, the Storer et al. (2006) raw field data probably should not have been adjusted for density-dependent mortality (Hibbard et al. 2010a). Unadjusted mortality from Storer et al. (2006) averaged $96.48 \%$. Data submitted to US EPA showed $5.8 \%$ survival on $B t$-maize DAS-59122-7 relative to non-Bt-maize, yielding an unadjusted mortality estimate of $94.2 \%$ (US EPA 2010b). Binning et al. (2010) showed low susceptibility of neonate WCR to $B t$-maize DAS59122-7, as well as a rapid decline in susceptibility of later instars; in their study, the mean survival of first, second and third instars exposed to $B t$-maize DAS59122-7 seedlings was $0.5,26$ and $65 \%$, respectively. Lefko et al. (2008) reported that the $\mathrm{F}_{1}$ generation of two WCR colonies reared on Bt-maize DAS-59122-7 in a laboratory experiment had mortality rates of 99.6 and $98.7 \%$ (see also Nowatzki et al. 2008).

When averaged across the environments tested, WCR mortality following exposure to $B t$-maize MIR604 under field conditions was $94.88 \%$ (Hibbard et al. 2010b) and $97.83 \%$ (Hibbard et al. 2011). US EPA (2007) reported on data provided by the applicant, and indicated that mortality of WCR due to $B t$-maize MIR604 ranged between $89.9 \%$ under artificial WCR infestation and $92.2 \%$ under natural WCR infestation (US EPA 2007).

In all studies reported above, the observed survival was $>100$-fold higher than the US EPA standard of $0.01 \%$ for a $B t$-crop that is truly high dose (Tabashnik and Gould 2012). These findings confirm that: (1) Bt-maize MON 863 and MON 88017, DAS-59122-7 and MIR604 fail to meet the high dose condition; and (2) that the expression of $B t$-toxins in these events is to be considered low-to-moderate. The ability of heterozygous resistant WCR progeny, resulting from the 
mating between individuals emerging from the refuge and $B t$-maize fields, to survive on $B t$-maize may diminish the efficacy of the HDR strategy to delay resistance evolution (Gassmann et al. 2011). Even though $B t$-maize MON 863 and MON 88017, DAS59122-7 and MIR604 do not express a concentration of $B t$-toxins that is truly high dose, root protection from WCR larval damage due to $B t$-maize is usually as good as, or better than is possible with a soil-applied insecticide. However, significant damage may still occur at high WCR infestation levels (Gray et al. 2007), or if Bt-maize plants are exposed to resistant WCR populations (Gassmann 2012).

As WCR is not extremely sensitive to Cry3Bb1, Cry34Ab1/Cry35Ab1 and mCry3A proteins and older instars are inherently less susceptible than neonates, larvae can survive the exposure to Diabrotica-active $B t$-maize. It has been postulated that larvae surviving on $B t$-maize may also do so by grazing on the outside of $B t$-toxin-expressing roots, thereby minimising exposure to $B t$-toxins. Root growing points are more metabolically active, and have a higher content in total soluble Bt-toxins compared with older root tissue (Lefko et al. 2008; Meissle et al. 2009). In the case of $B t$-maize MON 863, Clark et al. (2006) suggested that larvae may be able to detect subtle differences in the expression of the Cry3Bb1 protein in the root system and change their feeding behaviour to find non-toxic or less-toxic root parts, which would facilitate survival to the next instar with relatively normal larval growth (Hibbard et al. 2009). Data submitted to US EPA showed that first and second instars begin feeding on meristematic root tissue but terminated feeding on $B t$-maize MON 863, fed less frequently, did not become established at feeding sites, and moved more frequently than same-stage instars on the near-isogenic line. Larvae on the near-isogenic line fed into the root interior (i.e., tunnelling) and continued feeding resulted in larval movement into older and elongated root tissues over time (US EPA 2010a). Hibbard et al. (2005) also showed that both neonate and later instars preferred near-isogenic roots to Bt-maize MON 863 roots when a choice was possible. These results suggest that a repellent factor in roots or root exudates may contribute to the overall efficacy of $B t$-maize MON 863 (Hibbard et al. 2005; Clark et al. 2006; Murphy et al. 2010; US EPA 2010a). However, further investigation is required to confirm this hypothesis, and if so, to assess whether the larval feeding behavioural observations made on $B t$-maize MON 863 are relevant to other Diabrotica-active Bt-maize events. In the study by Petzold-Maxwell et al. (2012b), WCR larvae did not exhibit behaviour that leads to reduced exposure to Cry3Bb1 when given $B t$ - and non- $B t$-maize roots. Further, larval behavioural analyses with $B t$-maize MIR604 revealed that the presence of mCry $3 \mathrm{~A}$ in roots did not interfere with larval responses to infochemicals eliciting the key host location behaviours (attraction, feeding, and host recognition) (El Khishen et al. 2009; Bernklau et al. 2010). The efficacy of Bt-maize MIR604 is therefore attributed to antibiosis, rather than larval behavioural factors (antixenosis also called non-preference). There is also the possibility that $B t$-maize MON 88017, DAS-59122-7 and MIR604 may have a more even distribution of $B t$-toxins in their roots compared with $B t$-maize MON 863, resulting in more uniform exposure of larvae to the $B t$-toxin.

Initial resistance alleles are rare in the target insect pest population

The resistance alleles must be sufficiently rare [the frequency should be typically $<0.001$, which has been taken as a default value when modelling the evolution of resistance to $B t$-toxins (Roush 1994)], so that nearly all resistance alleles are in heterozygote genotypes that are eliminated by the $B t$-crop (Andow 2008). Studies, in which the frequency of resistance alleles to $B t$-toxins in populations of WCR are directly estimated, have not been published in the scientific literature, most likely due to the polygenic nature of the resistance (Lefko et al. 2008). In the case of $B t$ maize DAS-59122-7, evidence suggests complex inheritance of resistance, due to the involvement of one or more minor genes.

Data on the efficacy of $B t$-maize MON 863 in controlling WCR (Vaughn et al. 2005; Gray et al. 2007; Meihls et al. 2008; Hibbard et al. 2009) and baseline susceptibility of WCR populations to Cry3Bb1 (Siegfried et al. 2005; US EPA 2010a) have been used to provide indirect indications on the initial resistance allele frequency (US EPA 2010a; Onstad and Meinke 2010). Because initial resistance monitoring data did not reveal any apparent increase in susceptibility in WCR following several years of extensive cultivation of Cry3Bb1-expressing maize in the USA, it has been suggested that resistance allele 
frequencies to Cry3Bb1 may be $<0.01$ (but see US EPA 2010a). Based on the outcomes of the artificial selection experiments conducted by Lefko et al. (2008) and Meihls et al. (2008), Onstad and Meinke (2010) calculated that the initial resistance allele frequency may be as high as 0.2 for $B t$-maize MON 863, and ranges between 0.05 and 0.1 for $B t$-maize DAS-59122-7. High values for this parameter were required to match the rapid increase in fitness observed during artificial selection experiments. So far, no data on the initial resistance allele frequency have been published in the scientific literature for $B t$-maize MIR604. These results suggest that initial resistance alleles may be present at a higher frequency under field conditions than initially assumed, yet further research is required to corroborate this hypothesis.

\section{Random mating occurs between resistant insects emerging in Bt-crops and susceptible insects preserved on refuges at sufficient levels}

For the refuge to be effective its placement, configuration and size should ensure that resistant and susceptible insects mate more or less randomly, and that susceptible insects outnumber resistant ones. How much mixing and mating will occur between individuals emerging from the refuge and $B t$-maize fields is determined by the scale of adult movement. Even though adult WCR can move substantial distances (Coats et al. 1986; Toepfer et al. 2006; Carrasco et al. 2009) and perform sustained flights longer than 30 min (Coats et al. 1986; Naranjo 1990), most movements are quite local, and limited to short-ranged movements within fields or between adjacent fields, especially prior to mating (Naranjo 1990, 1991, 1994; Storer 2003; Meinke et al. 2009; Szalai et al. 2011). The range of adult movement measured in maize fields was shown to be $<30 \mathrm{~m}$ per day (Coats et al. 1987; Nowatzki et al. 2003; Spencer et al. 2003, 2005), with an average dispersal rate of approximately $15 \mathrm{~m}$ per day (Spencer et al. 2009). A microsatellite marker analysis among WCR populations (ten populations; 595 individuals sampled) across nine USA states (from western Kansas and Texas to New York and Delaware) found that all populations exhibited high levels of genetic diversity, exhibited little genetic differentiation as a whole across the geographic range sampled suggesting that movement is substantial, and that adults from adjacent locations exchanged genes more frequently than those from more distant locations (Kim and Sappington 2005). The tendency for short-distance dispersal may delay resistance evolution at a landscape level (Caprio and Tabashnik 1992), but it may contribute to the persistence and intensification of resistance in localised areas (Gassmann et al. 2011).

The pre-mating movement of WCR females is generally more limited than that of males, which can be extensive when responding to reproductive females (Meinke et al. 2009). Females are unlikely to disperse before mating, meaning that males are the primary dispersers before mating (Spencer et al. 2003; Marquardt and Krupke 2009). Mating typically occurs within 24-48 h of female adult emergence within the maize fields they emerged from or nearby. Males normally emerge before females and are capable of mating multiple times (on average two times during their lifespan), though they are less likely to mate as they age, whereas females generally mate only once (Kang and Krupke 2009a).

A concern is the non-synchronous emergence of WCR from refuge and $B t$-maize fields, as this could result in non-random (assortative) mating and contribute to resistance. Based on a series of laboratory experiments, Kang and Krupke (2009a) argued that the realised mating activity between susceptible males from refuges and potentially resistant females on Diabrotica-active $B t$-maize may be low, because the mating ability of males declines rapidly and adults in $B t$-maize may emerge later than those in the refuge. Murphy et al. (2010) reported an up to two weeks delay in initial emergence of WCR from $B t$-maize MON 863, compared to the near-isogenic line. In their field study, Clark et al. (2012) observed a delay in time of 18 days to $50 \%$ emergence from $B t$-maize MON 863. The delays in $50 \% \mathrm{WCR}$ emergence from Bt-maize DAS-59122-7 and MIR604 were shorter, averaging seven days for $B t$-maize DAS-59122-7 (Storer et al. 2006) and 4.1-6.5 days for Bt-maize MIR604 (US EPA 2007; Hibbard et al. 2011). Further, males have been shown to prefer larger females under laboratory conditions (Kang and Krupke 2009b), which could result in assortative mating too (Murphy et al. 2011). While caution must be exercised when extrapolating these laboratory results (Kang and Krupke 2009a, b) to field conditions (Carrière et al. 2012), they indicate that the larval ecological behaviour and adult mating behaviour of WCR and their 
quantitative measurements are complex, and that further investigations are required to sort out the demographics of populations emerging from refuges and $B t$-maize (Onstad et al. 2011).

Given that there is considerable movement of males, planting refuges for Diabrotica-active $B t$-maize adjacent to, or within the $B t$-maize field, preferentially in large blocks or as row strips of at least four or more rows, was considered adequate by US EPA $(2007,2010 a, b)$ to ensure that males from refuges encounter receptive females on $B t$-maize in time to mate. The rationale for wider row strips stems from concerns about larval movement, a major concern for $B t$-crops that are truly high dose (Mallet and Porter 1992), but this may be less critical for WCR (see "Seed blends"). IRM plans for WCR for $B t$-maize expressing a single $B t$-toxin require farmers to plant $20 \%$ of the $B t$-maize area into non-Btmaize, either within the $B t$-maize field as block or row strips, or adjacent to the $B t$-maize field (edges or headlands). In cases where larger fields are planted to Bt-maize, Gassmann et al. (2012) indicated that the effectiveness of a block refuge may be diminished due to the likely uneven dispersal of WCR with a higher density of insects near the refuge. Therefore, it is advisable to define the upper limit of the $B t$-maize surface at which interspersed block refuges should be established. Likewise, refuges planted as separate fields may only be effective if planted within a designated distance from the $B t$-maize field and be separated by no more than an alley or road from the $B t$-maize field. Since the life cycle of WCR extends over two consecutive maize growing seasons, EFSA (2011c) considered that separate fields designed to deliver susceptible WCR adults are suitable as refuge only if they have been cropped with non-Diabroticaactive $B t$-maize for at least two successive years in the EU.

To limit non-synchronous emergence of WCR from refuge and $B t$-maize fields, the type of maize to be planted as refuge should be of a similar hybrid/variety, as close as possible to the $B t$-maize. Refuge maize should therefore be selected based on equivalent maturity to $B t$-maize, and be planted within the same planting window as $B t$-maize. They should also be managed using comparable agronomic (fertilisation, weed and pest management and irrigation) practices. US EPA (2007, 2010a, b) considered it acceptable to treat refuges for $B t$-maize with seed treatments or soil- applied insecticides to control WCR larvae, as this is not expected to adversely affect adult emergence from the refuge. However, it is not acceptable to treat refuges for adult WCR control since these treatments may diminish the efficacy of the refuge. Foliar applications for adult control are an option only if both refuge and $B t$-maize fields are treated equally, and only if adult population densities are very high (US EPA 2007, 2010a, b).

\section{Resistance alleles are partially or fully recessive}

If resistance is completely recessive, then heterozygous offspring resulting from crosses between resistant and susceptible individuals are expected to be susceptible to the $B t$-toxin, thus preventing or slowing resistance evolution (Bates et al. 2005). The longest delays in resistance evolution are expected for resistance traits that are completely recessive. The dominance value $(h)$, which can be estimated based on the survival of susceptible and resistant genotypes after exposure to the $B t$-toxin, gives an indication on the inheritance of the resistance alleles, with values of 0 and 1 indicating completely recessive and completely dominant inheritance, respectively (Liu and Tabashnik 1997). As the survival of the susceptible target insect pest on a Bt-crop increases, resistance is expected to be more additive $(0.5)$ in nature, and at a sufficiently high level of survival, resistance may be dominant.

In the case of Bt-maize MON 863, Meihls et al. (2008) yielded hybrid progeny of WCR in reciprocal crosses that were incompletely recessive, and calculated an $h$ value of 0.285 for larvae and 0.296 for adults. Other researchers also assessed the inheritance of the Cry3Bb1 resistance through reciprocal crosses of a resistant and susceptible WCR colony, and concluded too that Cry3Bb1 resistance is inherited in a non-recessive manner (Petzold-Maxwell et al. 2012b). Using the data reported by Lefko et al. (2008), Onstad and Meinke (2010) determined that the $h$ values range from 0.5 to 0.75 for $B t$-maize DAS59122-7. So far, no dominance values have been reported for Bt-maize MIR604 in the scientific literature. The calculations of $h$ values point to nonrecessive inheritance of resistance under artificial selection experiments, which could accelerate the evolution of resistance in WCR in the field (Onstad and Meinke 2010; Pan et al. 2011). 
Fitness costs are associated with the resistance

Fitness costs associated with resistance occur when fitness on the non- $B t$-crop is lower for resistant insects than the susceptible ones (Gassmann et al. 2009). As the most likely cause of instability of resistance to a $B t$ toxin is the fitness cost associated with resistance (Tabashnik 1994), such costs could cause declines in resistance when the selection exerted by $B t$-maize ceases. In refuges where resistant insects are not exposed to the $B t$-toxin, fitness costs would exert control over the frequency of resistance alleles, and delay or reverse resistance by selecting against resistant genotypes, thereby increasing the effectiveness of refuges for delaying resistance (Gould 1998; Carrière and Tabashnik 2001; Crowder and Carrière 2009). Refuges would delay resistance evolution not only by providing susceptible individuals to mate with resistant individuals, but also by selecting against resistance. Gassmann et al. (2009) documented that the magnitude of fitness costs is positively correlated with resistance ratios, with more resistant strains suffering greater fitness costs. Based on reported resistance ratios (see "Laboratory- and greenhouse-selected resistance"), only low fitness costs are expected to be associated with resistance to $B t$-toxins in WCR.

Few studies have analysed fitness costs associated with Cry3Bb1, Cry34Ab1/Cry35Ab1 and mCry3A resistance in WCR, but preliminary data suggest that fitness costs associated with Cry3Bb1 resistance are minimal (French et al. 2008; Meihls et al. 2008; Bagley et al. 2009; Meihls 2010). Recently, Oswald et al. (2012) investigated the performance of Cry3Bb1 resistant WCR colonies reared on $B t$-maize MON 863 and its near-isogenic line. Analysis of survivorship, fecundity and viability on the near-isogenic line confirmed that no fitness costs are associated with Cry3Bb1 resistance. Meihls et al. (2008) reported little reduction in resistance after six generations of removal from selection in a laboratory-selected colony, showing that fitness costs (if any) were not significantly decreasing the resistance under the conditions studied. However, when Meihls (2010) considered fecundity, hatch rate and adult emergence (including percent female) of Cry3Bb1 resistant WCR colonies reared on the near-isogenic line together, the potential rate of increase per generation for selected colonies was 0.66 that of control colonies, suggesting some fitness costs were associated with Cry3Bb1 resistance in terms of female fecundity (Meihls LN, personal communication). Likewise, some fitness costs were reported by Gassmann et al. (2012), as some of the WCR populations they tested displayed significantly lower survival on non-Bt-maize than control populations.

Fitness costs associated with resistance can be influenced by several factors, including inter-specific interactions with entomopathogens (Gassmann et al. 2009). Entomopathogens can serve as biological control agents (Toepfer et al. 2008, 2009; Meissle et al. 2009; Petzold-Maxwell et al. 2012a). Theoretically, treating refuges with entomopathogens for the target insect pest could magnify fitness costs and be useful to delay resistance evolution. However, in their study, Petzold-Maxwell et al. (2012b) found no differences in survival among the four genotypic classes of WCR larvae (Cry3Bb1-resistant, Cry3Bb1susceptible, Cry3Bb1-resistant o crossed with Cry3Bb1-susceptible $\hat{\sigma}$, and Cry3Bb1-resistant $\hat{\sigma}$ crossed with Cry3Bb1-susceptible 9 ) reared on non$B t$-maize seedlings in the presence of different concentrations of the entomopathogenic nematode species Steinernema carpocapsae and Heterorhabditis bacteriophora (both of which can kill WCR larvae and occur in maize fields), indicating that Cry3Bb1 resistance in the presence of these two entomopathogenic nematodes is not associated with fitness costs.

Because most of the data indicate no fitness costs are associated with resistance to $\mathrm{Cry} 3 \mathrm{Bb} 1$, it is prudent to infer that major fitness costs are not necessarily present in field populations and thus, fitness costs may not help to substantially delay WCR resistance.

\section{Maize volunteers}

The extent with which Diabrotica-active Bt-maize volunteers in subsequent crops (including Diabroticaactive $B t$-maize) may affect the rate of resistance evolution is unclear (Marquardt et al. 2012). In the case of Bt-maize MON 863, Krupke et al. (2009) argued that the unpredictable and varying levels of the Cry $3 \mathrm{Bb} 1$ protein in the roots of volunteer plants may facilitate more rapid evolution of resistance in WCR populations; larvae may survive exposure simply because the dose is lower, even without any differential feeding behaviour. It is also possible that due to larval movement (Hibbard et al. 2005; Zukoff et al. 2012) larvae would be exposed to sublethal doses of the $\mathrm{Cry} 3 \mathrm{Bb} 1$ protein at later instar stages by feeding on a 
combination of volunteer and $B t$-maize plants (Meihls et al. 2008; Krupke et al. 2009; Murphy et al. 2010). However, there is also the possibility that larvae may exhibit a feeding behaviour that minimises exposure to $B t$-toxins. How much each of these mechanisms will contribute to the speed of resistance evolution overall is dependent upon the amount and type of $B t$-maize planted, the number of maize volunteers present and the level of $B t$-toxins expressed by those plants. The early and timely control of volunteer plants may decrease the potential selection pressure on WCR populations, as these plants would be killed before the larval development of WCR is completed (Olmer and Hibbard 2008; Marquardt et al. 2012).

Compliance with refuge requirements

Compliance with refuge requirements is a critical factor contributing to the success of IRM plans in delaying the rate at which resistance evolves (Bourguet et al. 2005; Kruger et al. 2009, 2012; Huang et al. 2011; Onstad et al. 2011).

\section{Education (training) programs}

In the case of $B t$-maize MON 863 and MON 88017, failure to fully comply with the refuge requirements and to carry out the operational details of IRM plans is likely to have contributed to the field-selected Cry3Bb1 resistance reported in the USA (Andow et al. 2010; Gassmann et al. 2011). A survey of farmers in the USA found that approximately $25 \%$ were not in compliance with refuge requirements in terms of either the size or location of refuges (Jaffe 2009). Model predictions by Pan et al. (2011) documented that resistance evolved faster when compliance levels declined: $70 \%$ compliance may roughly double the rate of resistance evolution when $20 \%$ block refuges that are in a fixed location are deployed. It is therefore important that education (training) programs form an integral part of IRM plans, as they aid farmers to understand the importance of adhering to IRM requirements and are key to the success of the HDR strategy (Glaser and Matten 2003; Bates et al. 2005; Andow 2008; Head and Greenplate 2012). IRM plans generally propose education programs and specific means for communicating IRM requirements such as technical user guides, newsletters, technical bulletins, product brochures, sales meetings, presentations by local experts to farmers, and the requirement to attend education meetings for purchase of the product. All of these can be used in addition to the traditional label that accompanies the Bt-crop and which outlines the contents of the product and standard directions for use (Alcalde et al. 2007; MacIntosh 2010). Besides education programs, compliance can be maximised via farmer contracts, certification tests, audits, rewards for compliance, crop insurance for refuges, databases of non-compliant farmers, sales restrictions, and fines for non-compliance.

\section{Seed blends}

Seed blends (also termed seed mixtures or refuge in a bag), composed of a 5-10\% blend of non-Bt-maize serving as refuge seed in the Diabrotica-active $B t$-maize seed bag, are approved for commercial cultivation in the USA (US EPA 2010c, 2011b). Seed blends will result in $100 \%$ compliance and are more convenient for farmers to plant than the usual block and row strip refuges (Onstad et al. 2011). The use of seed blends also distributes refuge plants relatively uniformly within the $B t$-crop field. Further, when compared with block refuges, WCR emerging from refuge plants emerges more synchronously with those emerging from Diabrotica-active $B t$-maize plants in seed blends. This increased proximity in both space and time may facilitate random mating between adults emerging from $B t$-maize and refuge plants compared with block refuges (Murphy et al. 2011). However, the advantages of seed blends may be offset by the potential for larval movement between roots of $B t$-maize and refuge plants, and the exposure of later instars to sublethal doses of the toxin (Goldstein et al. 2010; Murphy et al. 2011; Onstad et al. 2011; Razze and Mason 2012; Zukoff et al. 2012). For $B t$-crops that are truly high dose, Mallet and Porter (1992) indicated that the movement of larvae between $B t$-crop and refuge plants may lower the selective differential between susceptible and resistant genotypes, and increase the effective dominance of resistance by producing more heterozygote individuals (Glaum et al. 2012; Siegfried and Hellmich 2012; but see Tabashnik 1994).

Larval movement by WCR between $B t$-maize and refuge plants is partly understood (Schumann and Vidal 2012), and documented in both directions (Hibbard et al. 2003, 2004, 2005; Zukoff et al. 2012). Zukoff et al. (2012) found significantly more WCR beetles emerging from non-infested $B t$-maize 
plants when these plants were surrounded by two refuge plants as compared with any other plant configuration tested in one of the two years of the study. The authors postulated that larval movement from refuge to $B t$-maize plants would deliver additional susceptible individuals emerging from within the seed blend field, because much of their initial larval development was on refuge plants. In addition, older (later) instars are inherently less susceptible to $B t$-toxins and therefore have a greater potential to survive exposure to $B t$-toxins when moving from refuge to $B t$-maize plants (see " $B t$-toxin is expressed at appropriate levels in relevant plant parts"). These findings support the suggestion by Onstad (2006) of a reduced effect of late larval movement from the refuge to $B t$-maize plants that are not truly high dose on resistance evolution. Likewise, larvae finishing their development on refuge plants after being reared on $B t$-maize did not evolve resistance when assayed in a no-choice experiment with only $B t$-maize (Meihls et al. 2008). Binning et al. (2010) reported that the recovery of larvae that move from $B t$-maize to refuge plants may be close to 1.0 due to the relatively little selective differential existing between susceptible and resistant genotypes. Therefore, the effect on larvae from feeding on $B t$-maize is considered chronic and temporary, if $B t$-maize plants are surrounded by refuge plants and larvae move from the $B t$-maize to refuge plants. Whether resistance would have evolved in larvae that had been exposed to the $B t$-toxins for longer periods remains unclear (Zukoff et al. 2012).

Overall, resistance evolved more slowly under seed blend scenarios than for WCR colonies reared fully on $B t$-maize, indicating that the WCR biology seems to lend itself to the seed blend concept (US EPA 2009a). Fully rearing of WCR larvae on Bt-maize MON 863 led to resistance within three generations, while selection for resistance when first instars were fed the nearisogenic maize and third instars were fed $B t$-maize MON 863 led to the evolution of resistance within six generations of selection (Meihls et al. 2008).

\section{Resistance and compliance monitoring}

Resistance monitoring

IRM plans for $B t$-crops require routine monitoring for resistance evolution, so that early warning signs indicating increases in tolerance in the field may be detected (Siegfried and Spencer 2012). A timely detection of such signs enables actions to limit the survival of resistant insects and to slow or prevent their spread should resistance has evolved among field populations (Siegfried et al. 2007). Data generated through resistance monitoring also enables researchers and regulators to assess whether the HDR strategy delays resistance evolution in the target insect pest adequately and efficiently. Resistance monitoring programmes for $B t$-crops usually follow a twopronged approach, consisting of monitoring for changes in susceptibility to the Bt-toxin in the target insect pest, and monitoring of unexpected field damage caused by the pest (Glaser and Matten 2003; Bates et al. 2005; Alcalde et al. 2007; Andow 2008; MacIntosh 2010; Wilhelm et al. 2010; EFSA 2011b, 2012). Monitoring for WCR susceptibility is more likely to detect changes in susceptibility occurring at a broader spatial scale than reports of unexpected field damage that target the detection of localised resistance. Resistance monitoring is to be performed on a regular basis to ensure that any resistance is detected timely.

Baseline and monitoring WCR susceptibility to plantproduced Bt-toxins

Resistance monitoring aims to measure the baseline susceptibility of WCR to the Bt-toxin and shifts in that susceptibility over time. This baseline susceptibility represents the natural variability in response to the $B t$-toxin among WCR populations across their geographic distribution range prior to first introductions of $B t$-maize (Siegfried et al. 2005). Susceptibility is usually measured by sampling target pest insects from field populations, rearing their offspring in the laboratory, and determining how the progeny respond to diets containing the $B t$-toxin (Andow 2008; Tabashnik et al. 2008a, 2009; Siegfried and Spencer 2012). To obtain comparable data and to detect actual shifts in susceptibility at an early stage, a consistent methodology in terms of sampling, laboratory bioassays and toxin standardisation is required.

(1) It is recommended to utilise appropriate sampling strategies to collect individuals in the field; setting the most adequate and precise susceptibility baselines can be achieved through random sampling, whilst measuring shifts in that susceptibility can be 
realised through targeted sampling in areas where the selection pressure is believed to be highest and which correspond to those areas where WCR populations are known to regularly reach high infestation levels and where Diabrotica-active Bt-maize deployment is highest ('hotspot areas'). The target pest population needs to be large enough to provide sufficient numbers of healthy individuals for collection. Widely adopted guidelines for sampling corn borers recommend the sampling of 200 larvae, 200 adults, 100 mated females, or 100 egg masses per sampled population and set the minimum population size considered a valid sample for testing at 50 larvae, 50 adults, 25 mated females, or 25 egg masses. Similar guidelines for sampling WCR are under development (Siegfried and Spencer 2012). The sampling strategy should include fields cropped to Diabrotica-active Bt-maize and adjacent fields cropped to non-Diabrotica-active $B t$-maize or conventional maize, annual sampling during each maize growing season, follow-up sampling of the same populations in subsequent seasons and sampling at appropriate times. As resistance is less likely to evolve rapidly in maize areas with a low adoption rate of Diabrotica-active Bt-maize, sampling in such areas could be at a lower frequency, compared with hotspot areas, and serve to establish susceptibility baselines. Baseline data are established preferentially before the first introductions of the $B t$-maize, but at least during the initial years of launch prior to high market penetration. Ideally, the same areas should be monitored over time to reduce the natural geographical variation in susceptibility (Farinós et al. 2004, 2011, 2012; Saeglitz et al. 2006; Gaspers et al. 2011). Appropriately designed sampling strategies should account for the abundance, distribution and dispersal behaviour of WCR, and local variability in susceptibility levels.

(2) Most resistance monitoring studies have used insect diet bioassays to determine $\mathrm{LC}_{50}$ and $\mathrm{EC}_{50}$ values in individuals derived from field-collected populations exposed to $B t$-crops, and to compare those with that of susceptible laboratory reference or non-exposed field-derived colonies (Siegfried et al. 2007; Andow 2008; Tabashnik et al. 2008a, 2009; Siegfried and Spencer 2012). The estimation of $\mathrm{LC}_{50}$ and $\mathrm{EC}_{50}$ values and the establishment of doseresponse relationships require data from several toxin concentrations, and allow the calculation of resistance ratios. An increase in the resistance ratio indicates a decrease in susceptibility, which may be heritable. The dose-response bioassay method has proved adequate for documenting resistance that reached high levels, but is insensitive to small changes in resistance allele frequency, especially in the early stage of resistance evolution when resistance is first appearing and the frequency of resistant individuals is relatively low (Bourguet et al. 2005; Siegfried et al. 2007; Tabashnik et al. 2009; Siegfried and Spencer 2012).

Alternatively, susceptibility testing is performed with larvae $\left(\mathrm{F}_{1}\right.$ offspring) obtained from field-collected individuals using a diagnostic or discriminating dose of the Bt-toxin incorporated into an artificial diet (Siegfried et al. 2007; Andow 2008; Tabashnik et al. 2008a, 2009; Siegfried and Spencer 2012). Such a dose, when carefully selected, ensures $100 \%$ mortality of fully susceptible WCR populations ( $\mathrm{LC}_{99}$ ), survival of only resistant individuals, and discrimination between resistant and susceptible individuals. Decreased susceptibility and potential field-selected resistance are then demonstrated as the percent individuals surviving exposure to a fixed amount of the $B t$-toxin. Ideally, resistant individuals are needed to determine the discriminating dose, but in the absence of resistant individuals, some multiple of the $\mathrm{LC}_{50}$ or $\mathrm{LC}_{99}$ for susceptible larvae is commonly used (Andow 2008). The discriminating dose bioassay is a cost-effective method that allows the testing of many individuals at an appropriate dose, and will detect low frequencies of both polygenic and multiple resistance (Bates et al. 2005). However, Bourguet et al. (2005) indicated that the discriminating dose bioassay is more likely to detect dominant resistance alleles, and would be inefficient at detecting recessive alleles in heterozygotes (see also Siegfried and Spencer 2012). As individuals heterozygous for a recessive resistance allele have a susceptible phenotype, they will not survive the discriminating dose, and therefore reliable detection of allele frequencies below $10 \%(0.1)$ is impractical (Siegfried et al. 2007).

The $F_{2}$ screen was proposed as a method to detect rare and highly recessive resistance alleles in a heterozygous state (Andow and Alstad 1998, 1999; Andow and Ives 2002). This methodology involves establishing single-female family lines from a large number of field-collected individuals by inbreeding the offspring of each collected female within family lines. The offspring of these matings (i.e., the $F_{2}$ of the collected generation) are then screened at a 
discriminating dose to detect any homozygous individuals (Zhao et al. 2002). The purpose of the inbreeding process is to allow potentially heterozygous offspring of the field-collected females to mate with each other, generating a significant and easily detectible fraction of homozygous resistant offspring. Through back-calculation of the frequency of family lines containing a resistant allele, the frequency of the resistance allele in the sampled population can be estimated (Siegfried and Hellmich 2012; Siegfried and Spencer 2012). The $F_{2}$ screen is far more sensitive than a discriminating dose bioassay to detect recessive traits, though it does not allow detecting polygenic resistance (Zhao et al. 2002). Moreover, it does not require obtaining previously a resistant WCR colony. However, given the time and effort required for the $\mathrm{F}_{2}$ screen, the fact that resistance to Cry3Bb1, Cry34Ab1/ Cry35Ab1 and mCry $3 \mathrm{~A}$ is most likely polygenic and that resistance alleles may be more common than initially thought in WCR, the $\mathrm{F}_{2}$ screen may not offer significant benefits over the dose-response and discriminating dose bioassay.

The surface treatment of diet is usually utilised in diet bioassays to generate dose-response curves, or to discriminate between resistant and susceptible individuals. Instead of incorporating the toxin uniformly in the diet, it is added to the surface of the diet (e.g., Marçon et al. 1999; Siegfried et al. 2000, 2005; Farinós et al. 2004, 2011, 2012; Blanco et al. 2008; Gaspers et al. 2011). Important advantages of the surface treatment are the lower amount of Bt-toxin required for each test and the reduction in costs associated with $B t$-toxin preparation (Blanco et al. 2008). However, compared with the surface treatment, the incorporation technique allows a more homogenous distribution of the $B t$-toxin solution in the diet and thus a consistent exposure of each larva. As larvae may be exposed inconsistently to the $B t$-toxin when directly burrowing and feeding into the diet instead of grazing on the diet surface, this technique may be prone to error. However, a side-by-side comparison between the surface and incorporation treatment led to similar levels of variability in susceptibility, indicating that there are no major differences between both techniques (Saeglitz et al. 2006; Siegfried et al. 2007). Further, Siegfried and Spencer (2012) pinpointed that strict quality control of bioassays using surface treatment through visual inspection is essential to minimise potential inconsistencies in terms of non-uniform treatment and inconsistent exposure of larvae (see also Gaspers et al. 2011). Given the costs associated with $B t$-toxin preparation, its instability, and limitations in the amount that can be produced, Siegfried et al. (2007) considered that the advantages of the surface treatment outweigh the possible increased uniformity of exposure that may be associated with incorporating the $B t$-toxin in rearing diet.

Based on resistance monitoring data for Cry3Bb1 provided by the applicant, US EPA (2011a) concluded that all field-collected populations in Illinois, Iowa and Nebraska (USA) in 2009 had greater mean $\mathrm{LC}_{50}$ and $\mathrm{EC}_{50}$ values than those for the susceptible laboratory reference colony, in some instances by an order of magnitude. In the case of Cry34Ab1/Cry35Ab1, US EPA (2010b) considered there was a trend of decreasing susceptibility in WCR: all measured and extrapolated mean $\mathrm{LC}_{50}$ and $\mathrm{EC}_{50}$ values in WCR populations collected in Illinois, Iowa and Nebraska (USA) in 2008 were higher than those reported in previous years (2004-2005, 2006, 2007). However, the sensitivity of diet bioassays used to monitor WCR susceptibility in order to detect WCR resistance has been questioned (Nowatzki et al. 2008; Siegfried and Spencer 2012). This is because WCR larvae are not that susceptible to Cry3Bb1, Cry34Ab1/Cry35Ab1 and mCry $3 \mathrm{~A}$ (see " $B t$-toxin is expressed at appropriate levels in relevant plant parts"), so achieving significant mortality in WCR larvae can be challenging even at the highest toxin doses used. In addition, available WCR baseline susceptibility data for Cry3Bb1 (Siegfried et al. 2005; US EPA 2011a), Cry34Ab1/ Cry35Ab1 (US EPA 2011a) and mCry3A (US EPA 2007) have shown that the range of natural variation in baseline susceptibility can be greater than fivefold (Siegfried and Spencer 2012). Therefore, discerning populations with decreased susceptibility (but falling in the range of natural variation in baseline susceptibility) from those with actual resistance to the toxin can be problematic. The consequence is that small changes in toxin susceptibility, which could significantly affect product performance, could go undetected (Nowatzki et al. 2008).

Additional challenges are that artificial diets are prone to microbial contamination resulting in high rates of control mortality, WCR larvae may survive without feeding in three-day diet bioassays leading to an underestimation of the actual percent mortality due to toxin exposure, and that only one generation of 
WCR can be tested in a given year, as WCR is univoltine and its life cycle involves an obligatory egg diapause (US EPA 2011a; Siegfried and Spencer 2012). Therefore, alternative methods to the doseresponse and discriminating dose bioassays such as the sublethal seedling assay have been developed (Nowatzki et al. 2008) and applied to detect resistance in WCR (Lefko et al. 2008; Gassmann et al. 2011, 2012). The sublethal seedling assay consists of exposing populations of neonate WCR to seedlings from either $B t$-maize or the near-isogenic line for a fixed duration of time (usually 17 days), and to measure the total larvae recovered and age structure of the larval population. Delays in larval development are detected in the distribution of the different larval instars, which are determined based on head capsule width (Hammack et al. 2003). Higher proportions of later instars recovered on $B t$-maize roots during the fixed duration of exposure to maize roots indicate higher rates of larval population development and increased tolerance to the $B t$-maize event. This method has proved adequate to detect subtle changes in population susceptibility and is more sensitive than the standard diet bioassays that typically rely on mortality or growth inhibition as endpoints (Lefko et al. 2008; Nowatzki et al. 2008). This can be attributed to the more ecologically relevant larval exposure that is similar to that under field conditions, and to the use of the increased sensitivity of a sublethal endpoint (Lefko et al. 2008).

(3) The susceptibility of the target insect pest has been shown to vary considerably depending upon the source of $B t$-toxins used. Therefore, the same $B t$-toxin source should be used throughout the duration of resistance monitoring (Farinós et al. 2004; Saeglitz et al. 2006; US EPA 2011a).

\section{Unexpected field damage caused by WCR}

The monitoring of greater-than-expected-fielddamage due to WCR is an important component of the early detection of resistance, as it allows capturing early warning signs indicating increased tolerance in the field and reporting those timely. Greater-thanexpected-field-damage resulting from WCR control failures can easily be observed and reported by farmers, provided that farmers know what level of WCR damage is to be expected under various conditions and what level of WCR control is normally achieved (see Gassmann et al. 2011; Gray 2011a, b; US EPA 2011a). Ideally, a comparison of performance of $B t$-maize and refuge plants should occur; if damage levels on Bt-maize plants surpass economic thresholds and exceed those observed on refuge plants, then field resistance could be a concern. Such observations may reveal the occurrence of localised tolerance before it spreads, and may serve as a trigger for further investigation. For non-pyramided $B t$-maize (see "Discussion") US EPA (2011a) set the greater-thanexpected-field-damage threshold at 1.0 (node-injury scale, NIS; Oleson et al. 2005). Damage ratings of 1.0 in $50 \%$ of the sampled plants serve as a trigger: (1) to instruct farmers to use alternate WCR management options; and (2) to initiate sampling of WCR adults in the fields of concern for the purpose of further evaluation and laboratory testing to confirm potential resistance. If adult beetles cannot be collected from problem fields during the season, adult sampling should occur in the problem area the following season, irrespective of the pest infestation levels and damage in the problem year. Otherwise, early resistance events could be missed in these areas due to low population densities of WCR and root damage in the subsequent season, especially if farmers sprayed their fields or used another integrated pest management (IPM) tactic to manage their problem fields (US EPA 2011a). The majority of WCR adults do not disperse long distances, so the greatest probability to capture resistant genotypes is in problem fields and possibly, in adjacent fields. Sampling in neighbouring fields is reasonable during the following year, as adults may have moved from the problem fields to those fields, but only after in-field collection in problem fields have occurred.

Appropriate communication mechanisms should be in place for the timely reporting of farmer complaints regarding product performance. Farmer questionnaires, directed at farms or production systems where GM crops are grown, form an useful tool to collect and report first hand data on the performance and impacts of GM crops and their cultivation in the EU (Wilhelm et al. 2010; EFSA 2011a, b, 2012). This approach uses first-hand observations and relies on farmers' knowledge and experience of their local agricultural environments, comparative crop performance and other factors that may influence events on their land. Only if completed and submitted timely, farmer questionnaires could serve as an early-warning tool to report 
unexpected field damage caused by WCR larvae, which would trigger additional investigations, should alternative causes of unexpected field damage have been ruled out and the greater-than-expected-fielddamage threshold has been exceeded.

It is critical that responses to farmer complaints about product failure and hence greater-thanexpected-field-damage are taken timely, so that suspected resistance can be declared confirmed resistance and remedial measures be implemented, or be refuted without undue delays (Tabashnik and Gould 2012).

\section{Compliance monitoring}

Farmer questionnaires can also be designed to collect information on the implementation of refuges, technology adoption levels, and farmer use patterns (such as applied pest management practices). Such information will give indications on whether farmers followed and adhered to the refuge requirements when growing Diabrotica-active Bt-maize, and hence on compliance levels (EFSA 2011a, b, 2012). Specific questions on: the proportion of non-Bt-maize compared with $B t$-maize on the farm; refuge planting configurations; the distance between the refuge and the monitored $B t$-maize field if the refuge is planted as a separate field adjacent to the $B t$-maize field; differences in pest management practices of the refuge; and on whether the seperate refuge has been cropped with non- $B t$-maize for at least two successive years could be considered in farmer questionnaires. The reporting of non-compliance with refuge requirements, especially in areas where the uptake of $B t$-maize is high, may serve as a trigger to strengthen education (training) programs to aid farmers in understanding the importance of adhering to refuge requirements, and to impose penalties for non-compliance (such as the lack of access to the technology for deviations from the refuge requirements) (see "Compliance with refuge requirements"). Head and Greenplate (2012) indicated that compliance monitoring remains challenging due to the resources required to visit and to assess an appropriate number of farmers, and the potential bias present in telephone- and computer-based surveys. Compliance monitoring can also be achieved through surveys of farmers conducted by an independent third party.

\section{Remedial measures}

Besides implementing refuges of non- $B t$-maize, monitoring for resistance and compliance, and implementing education (training) programs, IRM plans provide a range of measures to respond to confirmed resistance. Remedial measures are intended to either mitigate the further evolution of resistance in other areas (prevent its spread) or eradicate resistance (if detected timely). It is considered very difficult to eradicate resistance, but slowing the spread of resistance genes is more practical. Meihls et al. (2008) reported that resistance remained at a similar level after six generations without selection in a laboratoryselected colony, suggesting that resistance may persist in a population (see also Gassmann et al. 2012; Storer et al. 2012a).

Remedial measures have multiple components, and knowledge about the nature and distribution of the resistance helps to determine what sort of remedial measures are needed to contain the spread of resistance (Head and Greenplate 2012). Options for remediation of confirmed resistance include: the use of alternate pest management options (e.g., through the use of conventional insecticides to control adults of WCR during the on-going season, applying alternative methods to deter the establishment of potentially resistant individuals during the following season, and rotating $B t$-maize with a nonmaize crop); monitoring to determine the resistance allele frequency (with rapid verification and alternate control strategies for verified resistance); sales suspensions of the affected product in the region; monitoring to determine the effectiveness of the implemented remedial measures; an assessment of how the resistance problem occurred; and appropriate procedures to inform relevant stakeholders (such as farmers, farmer organisations, crop consultants, seed suppliers, local academic/scientific experts and industry players) and regulatory authorities (Glaser and Matten 2003; Alcalde et al. 2007; MacIntosh 2010; US EPA 2011a). In the case of $B t$-maize MON 88017, US EPA 2011a recommended that remedial measures are put in place in areas experiencing greater-than-expected-field-damage; such measures may remain implemented until restoration of susceptibility to Cry3Bb1 has been demonstrated. 


\section{Discussion}

The global cultivation area of GM crops [including soybean, maize, cotton, canola (oilseed rape) and sugar beet] has consistently increased since they were first cultivated commercially in 1996, reaching 160 million hectares in 2011. By 2011, the global area planted to $B t$-crops was 66 million hectares. The rapid adoption of $B t$-crops indicates that they have become a primary tool for managing mayor lepidopteran and coleopteran target pest species in cotton and maize. A concern is, however, that the selection pressure exerted by the widespread cultivation of $B t$-crops increases the risk of target insect pests to evolve resistance to plant-produced $B t$-toxins, as resistant populations could affect the sustainable use of $B t$-crops and alter pest management options.

To delay resistance evolution, IRM plans relying on the HDR strategy have been implemented for several $B t$-crops in several countries. The lack of resistance in some major insect pests targeted by Bt-crops attests that the HDR strategy is capable to prevent or at least delay resistance under field conditions, despite 15 years of intensive use of some Bt-crops (Andow 2008; Tabashnik et al. 2008a, b, 2009; Huang et al. 2011; Siegfried and Hellmich 2012). In contrast, when the conditions contributing to the success of the HDR strategy were not met, field-selected resistance to $B t$-crops has occurred. Instances of field-selected resistance to $B t$-maize have been reported in populations of the African stem borer (Busseola fusca) in South Africa (van Rensburg 2007; Kruger et al. 2009, 2011), and in populations of the fall armyworm (Spodoptera frugiperda) in Puerto Rico (Matten et al. 2008; Moar et al. 2008; Tabashnik 2008; Tabashnik et al. 2008a; Storer et al. 2010, 2012a), where larvae were able to survive on Cry1Abexpressing Bt-maize MON 810 and Cry1F-expressing $B t$-maize TC1507, respectively. Reasons for these instances of field-selected resistance range from the insufficient planting of refuges of non- $B t$-maize in South Africa to the autosomally, non-recessive inheritance of resistance by S. frugiperda in Puerto Rico, and specific agronomic/environmental factors (Huang et al. 2011). South African farmers declared nonirrigated conventional maize as refuges for irrigated $B t$-maize, which most likely decreased random mating and egg laying, as moths prefer high humidity (van Rensburg 2007; Kruger et al. 2011). In Puerto Rico, factors that may have contributed to unprecedented levels of selection pressure on $S$. frugiperda populations are: continuous year-round planting of $B t$-maize; limited migration from external ecosystems (island geography); and drought conditions that concentrated pest populations in irrigated fields (Storer et al. 2010, 2012a).

Gassmann et al. (2011) reported the first instance of field-selected Cry3Bb1 resistance in WCR in Iowa (USA). They found significantly higher survival of WCR larvae on Bt-maize MON 88017 when from fields suffering severe WCR feeding damage, than when from control fields. Common features of affected fields include a history of continuous planting to Cry3Bb1-expressing $B t$-maize for multiple successive years, the use of this $B t$-maize as sole pest management option against WCR, non-compliance with refuge requirements, and most likely high WCR infestation levels. Of additional concern are data suggesting that several conditions contributing to the success of the HDR strategy may not be met for $B t$ maize MON 863 and MON 88017, DAS-59122-7 and MIR604 and WCR: (1) the $B t$-toxins are expressed heterogeneously at a low-to-moderate dose in roots from $B t$-maize MON 863 and MON 88017, DAS59122-7 and MIR604; (2) resistance alleles may be present at a higher frequency than initially assumed; (3) WCR may mate in a non-random manner; (4) resistance traits could have non-recessive inheritance; and (5) fitness costs may not necessarily be associated with resistance. While these factors are expected to increase the risk of WCR to evolve resistance, models developed to estimate the evolution of resistance in WCR populations predicted that a $20 \%$ refuge can delay resistance evolution for $B t$-maize under certain conditions (Onstad et al. 1999, 2001a, b; Storer 2003; Crowder and Onstad 2005; Crowder et al. 2005, 2006; US EPA 2007, 2010a, b; Onstad and Meinke 2010; Pan et al. 2011). In some of these models, a range of efficacy and genetic parameter values were explored; adaptation to low-to-moderate dose Bt-crops were simulated by accounting for the fact that many or most of the individuals surviving on $B t$-crops have susceptible phenotypes; multi-locus models for resistance were considered instead of single-locus, two-allele models for resistance; a spatially-explicit model structure was accounted for; and more realistic data on the biology of WCR were integrated. Depending on the underlying model assumptions and parameter values used in these models, which explore more or 
less conservative scenarios, resistance has been predicted to evolve in three to more than 20 years. With a $20 \%$ block refuge planted every year in the centre of a $B t$-maize field of 80 ha, Pan et al. (2011) estimated delays in resistance of at least 20 years when the initial resistance allele frequency was 0.001 . For an initial resistance allele frequency of 0.01 the resistance allele frequency was likely to exceed $50 \%(0.5)$ in seven years. With the annual relocation of the $20 \%$ block refuge, the resistance allele frequency would exceed $50 \%$ in nine and five years, if the initial resistance allele frequencies were 0.001 and 0.01 , respectively. Without adequate risk management strategies, resistance evolved in five and three years for initial resistance allele frequencies of 0.001 and 0.01 , respectively (Pan et al. 2011). Similar trends were reported for dominance; as the $h$ value increased, the time to $50 \%$ allele frequency decreased. For cases of additive resistance $(h=0.5)$ resistance was predicted to evolve in 7-11 years under $20 \%$ block refuge scenarios (Onstad and Meinke 2010). However, Tabashnik and Gould (2012) pinpointed that resistance may evolve faster, as initial resistance allele frequencies in WCR may be 20-200 times higher than typical empirical estimates of $0.01-0.001$ for other target insect pests (Carrière et al. 2010; Onstad and Meinke 2010). Further, modelling predictions often assume complete compliance with refuge requirements (Pan et al. 2011; Gassmann 2012).

Glaser and Matten (2003) observed that effective IRM may still be possible under non-high dose conditions. If the high dose condition of the HDR strategy is not achieved, model predictions indicated that resistance evolution can be delayed by requiring restrictions on the management of these refuges (Andow 2008), or by increasing refuge abundance to compensate for survival of hybrid progeny on Bt-crops (Gould 1998; Tabashnik et al. 2004). In the latter case, the strategy for managing resistance in WCR would rely solely on a refuge to maintain a susceptible population (Murphy et al. 2010). Tabashnik and Gould (2012) recently advocated increasing refuge abundance by requiring a $50 \%$ refuge of non- $B t$-maize instead of the current $20 \%$ for the first generation of Diabrotica-active $B t$-maize; modelling suggested that a $50 \%$ refuge would delay the time to resistance at least twice as the current $20 \%$ refuge. As the effectiveness of larger refuges may be diminished by the likely uneven dispersal of WCR under certain configurations, the authors recognised the need to finetune their recommendation and to account for different spatial configurations of refuges. Refuge configurations for Diabrotica-active Bt-maize are best optimised within the $B t$-maize field as row strips or seed blends. Both modelling and retrospective analysis of resistance and compliance monitoring data in conjunction with spatial and temporal distribution of $B t$ maize and refuges may support the development of optimal refuge recommendations on a case-by-case basis (Carrière et al. 2012). Nonetheless, depending on refuge configurations, increased refuge abundance may have economic trade-offs that may offset incentives to implement refuges leading to reduced farmer compliance, or to adopt the technology.

As WCR larvae feeding on $B t$-maize roots may not be exposed to $B t$-toxins uniformly due to their heterogeneous expression (see " $B t$-toxin is expressed at appropriate levels in relevant plant parts"), $B t$-maize itself may also act as refuge (Meihls et al. 2011). Hibbard et al. (2010b) demonstrated that many or most of WCR individuals initially surviving on Btmaize MIR604 after one generation of selection in the field had a susceptible phenotype, suggesting that resistant individuals from the $B t$-maize are not only mating with susceptible individuals from the refuge, but also with susceptible individuals that emerged from the $B t$-maize field. $B t$-maize that is not truly high dose could thus yield susceptible adults that are available to mate with any WCR potentially carrying resistance alleles, and hence contribute to slow the onset of resistance evolution (Crowder and Onstad 2005). Further, evidence has shown that several grass species can support the growth of WCR larvae (Clark and Hibbard 2004; Oyediran et al. 2004; Wilson and Hibbard 2004; Breitenbach et al. 2005) and may therefore serve as an additional (unstructured) refuge where such host plants are abundant and appropriately distributed (Chege et al. 2005, 2009; Oyediran et al. 2005).

The most effective and sustainable use of $B t$-crops is as a component of an IPM approach (Porter et al. 2012). The basic goal of an IPM is to achieve effective crop protection in a manner that provides sustainable economic benefits to farmers and society, and minimal impact on the environment. IPM proscribes the use of multiple tactics to suppress target insect pest populations, and to prevent or at least delay resistance evolution. The incorporation of Bt-crops with current integrated approaches to pest management will 
therefore help ensure their long-term sustainability (Meissle et al. 2011b).

(1) Crop rotation is a key component of IPM, and is an effective tool to manage WCR in areas where no crop rotation-resistant WCR variant occurs. If Diabrotica-active $B t$-maize is followed by a different crop in the consecutive spring, then hatched WCR larvae do not find enough food and starve quickly (Levine and Oloumi-Sadeghi 1991; Kiss et al. 2005b, Boriani et al. 2006; Meissle et al. 2011b). Overall, maize-based cropping systems comprise different shares of maize (FCEC 2009; Meissle et al. 2010; Vasileiadis et al. 2011) and different egg-laying habitats and feeding sources for WCR, and are sufficiently diverse to maintain WCR infestation levels below economically damaging thresholds. However, maize is often grown continuously or in short crop rotations comprising just two permanent crops. Continuous maize-soybean crop rotations pose a high selection pressure on WCR and favour those WCR individuals expressing reduced ovipositional fidelity to maize fields (Spencer et al. 2005), as it has been shown in the USA (Levine and Oloumi-Sadeghi 1996; Levine et al. 2002; Gray et al. 2009). To delay the evolution of resistance to $B t$-toxins in WCR, or of a crop rotation-resistant WCR variant, sufficient diversity in crop rotations in space and time should be ensured, ideally at a regional scale. Alternating $B t$-maize with another crop whenever possible is therefore considered useful, especially in fields with a high probability of WCR infestation levels.

(2) Additional essential components of IPM, as practiced with plant protection products, are the alternation of insecticides with different modes of action, and the application of insecticides when and where necessary. Porter et al. (2012) indicated that rotation of $B t$-maize expressing different $B t$-toxins as a WCR management strategy has been neglected in the USA. In areas with significant WCR infestation levels, $B t$-maize expressing the same $B t$-toxin is often planted in the same field year after year (Gassmann et al. 2011; Gray 2011a, b; US EPA 2011a). The use of a $B t$-maize expressing a different $B t$-toxin than the one that performed poorly in the previous year would avoid repeated selection pressure.

Further, Diabrotica-active Bt-maize is being used prophylactically in US areas with little or no need for it. Under these conditions, Porter et al. (2012) argued that planting non-Diabrotica-active $B t$-maize can be profitable and should be one of the IPM tools to maintain sustainability of $B t$-maize; non-Diabroticaactive $B t$-maize, used in conjunction with soil-applied insecticides or not, would not cause selection for resistance. In addition, Kiss et al. (2005b) postulated that non-Diabrotica-active Bt-maize grown continuously for up to three consecutive years within crop rotation areas may serve as a refuge, delay the evolution of a crop rotation-resistant WCR variant and may preserve crop rotation as a means for WCR management, though this may have economic tradeoffs. Treatment of Diabrotica-active Bt-maize with insecticides targeting WCR should only be considered under special circumstances (see "Unexpected field damage caused by WCR and remedial measures"), and is therefore not a recommended routine management strategy, as it masks the geographic extent and in-field severity of $B t$-resistance and selects for resistance to the insecticides (Porter et al. 2012). To achieve effective and long-term crop protection, the decision to apply WCR management measures should be based on scouting, past experience and the population density of adult WCR in the preceding year's crop.

(3) The landscape of Diabrotica-active Bt-maize is changing quickly with several new products being at various development stages or close to commercialisation, offering additional means for WCR management. This new cohort of products combines existing $B t$-toxins, rely on new Bt-toxins, or are based on alternative strategies involving a different mode of action than $B t$-toxins. Pyramided $B t$-maize expressing amongst others the Cry3Bb1 + Cry34Ab1/Cry35Ab1 or the Cry34Ab1/Cry35Ab1 + mCry3A proteins have been registered for commercial cultivation in the USA (US EPA 2009b, 2011c) (Table 1). Since the binary Cry34Ab1/Cry35Ab1 proteins require both proteins to be toxic (neither is toxic by itself), $B t$-maize DAS59122-7 is not considered pyramided. Further, $B t$-maize expressing a hybrid-like toxin Cry1 Ab/ Cry3A protein (eCry3.1Ab) pyramided with mCry3A is in the commercialisation pipeline (Walters et al. 2010; Hibbard et al. 2011). The use of RNA interference for the management of target insect pests holds considerable promise (Burand and Hunter 2012), and its potential was recently demonstrated in the case of WCR larvae (Baum et al. 2007) and adults (Rangasamy and Siegfried 2011). Baum et al. (2007) reported that RNA interference caused larval mortality in feeding assays using exposure to double-stranded 
RNA, and that maize plants expressing doublestranded RNA exhibited reduced root damage from larval feeding of WCR.

The pyramiding in the same plant of two or multiple toxins acting independently on WCR midgut receptors is expected to delay the evolution of resistance to either toxin effectively when most individuals that are resistant to one toxin are killed by the other, and when selection for resistance to one of the toxins does not cause cross-resistance to the other (Roush 1998; Zhao et al. 2005). In the absence of cross-resistance, model predictions by Onstad and Meinke (2010) showed that evolution of resistance to a $B t$-toxin in WCR is generally delayed by pyramided traits in $B t$-maize compared with two single traits deployed sequentially. However, in populations where WCR has begun adapting or has evolved resistance to one of two $B t$-toxins, the benefit from pyramiding may be diminished or offset, respectively. Porter et al. (2012) and Tabashnik and Gould (2012) argued that for populations of WCR resistant to Cry3Bb1 Bt-maize expressing the Cry3Bb1 + Cry34Ab1/Cry35Ab1 proteins are not fully an effective pyramid due to the reduced efficacy of Cry3Bb1. The efficacy of pyramided $B t$-maize will also be diminished if cross-resistance occurs. However, factors facilitating greater larval survival on pyramided $B t$-maize than the additive effect of the individual proteins have not been identified yet (Hibbard et al. 2011). Further, Gassmann et al. (2011, 2012) reported that there was no significant correlation among WCR populations for survival on $B t$-maize DAS-59122-7 and MON 88017. Offspring from WCR collected from $B t$-maize MON 88017 problem fields and control fields had a similar survival on maize seedlings of $B t$-maize DAS-59122-7 and the near-isogenic line, suggesting a lack of cross-resistance between Cry3Bb1 and Cry34Ab1/Cry35Ab1 (Gassmann et al. 2011, 2012). Because Cry3Bb1 is a typical three domain-like toxin and has no sequence similarity with the binary-like toxin Cry34Ab1/Cry35Ab1 (Bravo and Soberón 2008), it acts on WCR midgut receptors independently from Cry34Ab1/Cry35Ab1 (US EPA 2010a, b; Gassmann 2012; Gassmann et al. 2011, 2012). Cry3Bb1 is, however, more similar to mCry3A than Cry34Ab1/ Cry35Ab1, and therefore cross-resistance is more likely between Cry3Bb1 and mCry3A (Rausell et al. 2004; Crickmore et al. 2012).

The transition to pyramided $B t$-maize only is ongoing (Storer et al. 2012b), but the current landscape of Diabrotica-active $B t$-maize comprises a mosaic of $B t$-maize expressing a single or multiple toxins. This situation poses a challenge, as mosaics could theoretically foster the evolution of resistance to pyramided $B t$-maize if WCR evolved resistance to a single toxin $B t$-maize that is also used in pyramided $B t$-maize (Gould 2003; Zhao et al. 2005; Siegfried and Hellmich 2012). Therefore, releasing $B t$-maize initially as pyramids rather than single events followed by pyramids is a better resistance management strategy (Gassmann et al. 2012), provided that the frequency of resistance alleles is low (Roush 1998; Gould et al. 2006; Onstad and Meinke 2010).

Whilst empirical data will be needed for each of these new Diabrotica-active Bt-maize products to develop optimised IRM plans to delay the evolution of resistance (Tabashnik and Gould 2012), they offer alternative means to manage WCR, and can complement existing management options under certain conditions. Unlike three domain-like Cry3 toxins (e.g., Raybould et al. 2007; Devos et al. 2012), however, the safety of some of these products to human and animal health and the environment has yet to be investigated fully (CERA 2011).

\section{Conclusion}

Data from both artificial laboratory and greenhouse selection experiments and the field show that there are limits to the durability of the first generation of Diabrotica-active Bt-maize MON 863 and MON 88017, DAS-59122-7 and MIR604 if farmers use the same $B t$-maize repeatedly and exclusively. Selected WCR populations have evolved resistance to plantproduced Cry3Bb1, Cry34Ab1/Cry35Ab1 and mCry3A proteins from $B t$-maize $\mathrm{MON} 863$ and MON 88017, DAS-59122-7 and MIR604, respectively, in twelve of the twelve attempts under laboratory and greenhouse conditions. In all artificial selection experiments reported, resistant WCR populations were yielded rapidly under conditions of continuous exposure. Field-selected resistance of WCR to Cry $3 \mathrm{Bb} 1$ is documented in some US maize growing areas, where an increasing number of cases of unexpected WCR damage to $B t$-maize MON 88017 has been reported, so there is concern that Cry3Bb1 resistance is becoming widespread. Common features of affected maize fields include amongst others a 
history of continuous planting to Cry3Bb1-expressing $B t$-maize for multiple successive years and the use of this $B t$-maize as sole pest management option against WCR. These practices are, however, not a sound component of effective IPM. To ensure effective longterm WCR management and the sustainable use of $B t$ maize, an IPM approach in which $B t$-maize is only one of many management options should be deployed.

Currently implemented IRM plans, designed to delay resistance evolution in target insect pests to Btcrops, usually rely on the HDR strategy. Evidence (including laboratory, greenhouse and field data), suggesting that several conditions contributing to the success of the HDR strategy may not be met for WCR and Bt-maize MON 863 and MON 88017, DAS59122-7 and MIR604, raises concern about the appropriateness of the current resistance management for $B t$-maize targeting this pest. Model predictions suggest that a $20 \%$ refuge of non-Diabrotica-active $B t$-maize can delay resistance evolution in WCR under certain conditions. Because each model is subject to scientific uncertainty, caution is recommended when predicting future responses of WCR in specific regions based on other target insect pest species, or on experiences elsewhere, as resistance evolution is dependent upon many factors (Tyutyunov et al. 2008). Caution must also be exercised when extrapolating laboratory and greenhouse results to field conditions (Carrière et al. 2012). Field-scale assessments and further research are therefore needed to confirm the adequacy and efficacy of the currently proposed HDR strategy in delaying resistance evolution in WCR, and to resolve the remaining scientific uncertainty related to the appropriateness of this strategy. To compensate for the survival of hybrid progeny of WCR on Bt-maize that is not truly high dose, Tabashnik and Gould (2012) recommended increasing refuge abundance, though this may have economic trade-offs and may offset implementation incentives for farmers. Failure to fully comply with refuge requirements and to carry out the operational details of IRM plans are likely to have contributed to the field-selected Cry3Bb1 resistance in WCR, so measures maximising compliance may help increase refuge abundance.

Resistance monitoring to detect early warning signs indicating resistance evolution in the field, compliance monitoring to assess farmers' compliance with IRM requirements, and education (training) programs aiding farmers to understand the importance of adhering to IRM requirements are essential to the success of the HDR strategy and should therefore continue to form an integral part of IRM plans for $B t$ maize.

Acknowledgments We thank the experts of the Environment Working Group on GMO applications of the EFSA GMO Panel for inspiring discussions that helped to develop this publication, and two anonymous reviewers for insightful comments that helped to improve this publication. We thank Anthony Zukoff (USDA-ARS, Columbia, MO, USA) for western corn rootworm photos.

\section{References}

Alcalde E, Amijee F, Blache G, Bremer C, Fernandez S, GarciaAlonso M, Holt K, Legris G, Novillo C, Schlotter P, Storer $\mathrm{N}$, Tinland B (2007) Insect resistance monitoring for $B t$ maize cultivation in the EU: proposal from the industry IRM working group. J Consum Prot Food Saf 2(S1):47-49

Alstad DA, Andow DA (1995) Managing the evolution of insect resistance to transgenic plants. Science 268:1894-1896

Andow DA (2008) The risk of resistance evolution in insects to transgenic insecticidal crops. Collect Biosaf Rev 4: 142-199

Andow DA, Alstad DA (1998) $\mathrm{F}_{2}$ screen for rare resistance alleles. J Econ Entomol 91:572-578

Andow DA, Alstad DN (1999) Credibility interval for rare resistance allele frequencies. J Econ Entomol 94:755-758

Andow DA, Ives AR (2002) Monitoring and adaptive resistance management. Ecol Appl 12:1378-1390

Andow DA, Farrell SL, Hu Y (2010) Planting patterns of in-field refuges observed for $B t$ maize in Minnesota. J Econ Entomol 103:1394-1399

Aragón P, Lobo JM (2012) Predicted effect of climate change on the invasibility and distribution of the western corn rootworm. Agric For Entomol 14:13-18

Areal FJ, Riesgo L, Rodríguez-Cerezo E (2012) Economic and agronomic impact of commercialized GM crops: a metaanalysis. J Agric Sci. doi:10.1017/S0021859612000111

Bagley M, Oswald K, French BW, Nielson CN (2009) Fitness of $B t$-resistant western corn rootworm on Mon863 and isoline corn. IWGO meeting, Munich, Germany, April 5-8, 2009

Ball HJ, Weekman GT (1962) Insecticide resistance in the western corn rootworm in Nebraska. J Econ Entomol 55:439-441

Bates SL, Zhao J-Z, Roush RT, Shelton AM (2005) Insect resistance management in GM crops: past, present and future. Nat Biotechnol 25:57-62

Baum JA, Bogaert T, Clinton W, Heck GR, Feldmann P, Ilagan O, Johnson S, Plaetinck G, Munyikwa T, Pleau M, Vaughn T, Roberts J (2007) Control of coleopteran insect pests through RNA interference. Nat Biotechnol 25:1322-1326

Bernklau EJ, Hibbard BE, Bjostad LB (2010) Antixenosis in maize reduces feeding by western corn rootworm larvae (Coleoptera: Chrysomelidae). J Econ Entomol 103:20522060 
Binning RR, Lefko SA, Millsap AY, Thompson SD, Nowatzki TM (2010) Estimating western corn rootworm (Coleoptera: Chrysomelidae) larval susceptibility to event DAS59122-7 maize. J Appl Entomol 134:551-561

Blanco CA, Storer NP, Abel CA, Jackson R, Leonard R, Lopez JD, Payne G, Siegfried BD, Spencer T, Terán-Vargas AP (2008) Baseline susceptibility of tobacco budworm (Lepidoptera: Noctuidae) to Cry1F toxin from Bacillus thuringiensis. J Econ Entomol 101:168-173

Boriani M, Agosti M, Kiss J, Edwards CR (2006) Sustainable management of the western corn rootworm, Diabrotica virgifera virgifera LeConte (Coleoptera: Chrysomelidae), in infested areas: experiences in Italy, Hungary and the USA. EPPO Bull 36:531-537

Bourguet D, Desquilbet M, Lemarié S (2005) Regulating insect resistance management: the case of non-Bt corn refuges in the US. J Environ Manag 76:210-220

Bravo A, Soberón M (2008) How to cope with insect resistance to $B t$ toxins? Trends Biotechnol 26:573-579

Bravo A, Gómez I, Porta H, García-Gómez BI, RodriguezAlmazan C, Pardo L, Soberón M (2012) Evolution of Bacillus thuringiensis Cry toxins insecticidal activity. Microbial Biotechnol. doi:10.1111/j.1751-7915-2012.00342.x

Breitenbach S, Heimbach U, Lauer KF (2005) Field tests on the host range of the larvae of the western corn rootworm (Diabrotica virgifera virgifera LeConte 1868, Chrysomelidae, Coleoptera). Nachrichtenbl Deut Pflanzenschutzd 57:241-244

Burand JP, Hunter WB (2012) RNAi: future in insect management. J Invertebr Pathol. doi:10.1016/j.jip.2012/07.012

Caprio MA, Tabashnik BE (1992) Gene flow accelerates local adaptation among finite populations: simulating the evolution of insecticide resistance. J Econ Entomol 85:611-620

Carpenter JE (2010) Peer-reviewed surveys indicate positive impact of commercialized crops. Nat Biotechnol 28:319-321

Carrasco LR, Harwood TD, Toepfer S, MacLeod A, Levay N, Kiss J, Baker RHA, Mumford JD, Knight JD (2009) Dispersal kernels of the invasive alien western corn rootworm and the effectiveness of buffer zones in eradication programmes in Europe. Ann Appl Biol 156:63-77

Carrière Y, Tabashnik BE (2001) Reversing insect adaptation to transgenic insecticidal plants. Proc R Soc B Biol Sci 268:1475-1480

Carrière Y, Crowder DW, Tabashnik BE (2010) Evolutionary ecology of insect adaptation to Bt crops. Evol Appl 3:561-573

Carrière Y, Ellers-Kirk C, Harthfield K, Larocque G, Degain B, Dutilleul P, Dennehy TJ, Marsh SE, Crowder DW, Li X, Ellsworth PC, Naranjo SE, Palumbo JC, Fournier A, Antilla L, Tabashnik BE (2012) Large-scale, spatially explicit test of the refuge strategy for delaying insecticide resistance. Proc Natl Acad Sci USA 109:775-780

CERA (2011) Problem formulation for the environmental risk assessment of RNAi plants: conference proceedings. http:// cera-gmc.org/docs/cera_publications/pub_08_2011.pdf

Chege PG, Clark TL, Hibbard BE (2005) Alternate host phenology affects survivorship, growth and development of western corn rootworm (Coleoptera: Chrysomelidae) larval biology. Environ Entomol 34:1441-1447
Chege PG, Clark TL, Hibbard BE (2009) Initial larval feeding on an alternate host enhances western corn rootworm (Coleoptera: Chrysomelidae) beetle emergence on Cry3Bb1expressing maize. J Kansas Entomol Soc 82:63-75

Ciosi M, Miller NJ, Kim KS, Giordano R, Estoup A, Guillemaud $\mathrm{T}$ (2008) Invasion of Europe by the western corn rootworm, Diabrotica virgifera virgifera: multiple transatlantic introductions with various reductions of genetic diversity. Mol Ecol 17:3614-3627

Ciosi M, Miller NJ, Toepfer S, Estoup A, Guillemaud T (2011) Stratified dispersal and increasing genetic variation during the invasion of Central Europe by the western corn rootworm, Diabrotica virgifera virgifera. Evol Appl 4:54-70

Clark TL, Hibbard BE (2004) Comparison of nonmaize hosts to support western corn rootworm (Coleoptera: Chrysomelidae) larval biology. Environ Entomol 33:681-689

Clark PL, Vaughn TT, Meinke LJ, Molina-Ochoa J, Foster JE (2006) Diabrotica virgifera virgifera (Coleoptera: Chrysomelidae) larval feeding behavior on transgenic maize (MON 863) and its isoline. J Econ Entomol 99:722-727

Clark TL, Frank DL, French BW, Meinke LJ, Moellenbeck D, Vaughn TT, Hibbard BE (2012) Mortality impact of MON863 transgenic maize roots on western corn rootworm larvae in the field. J Appl Entomol. doi:10.1111/ j.1439-0418.2012.01709.x

Coats SA, Tollefson JJ, Mutchmor JA (1986) Study of migratory flight in the western corn rootworm. Environ Entomol 15:1-6

Coats SA, Mutchmor JA, Tollefson JJ (1987) Regulation of migratory flight by juvenile hormone mimic and inhibitor in the western corn rootworm (Coleoptera: Chrysomelidae). Ann Entomol Soc Am 80:697-708

Crickmore N, Zeigler DR, Schnepf E, Van Rie J, Lereclus D, Baum J, Bravo A, Dean DH (2012) Bacillus thuringiensis toxin nomenclature. http://www.lifesci.sussex.ac.uk/home/ Neil_Crickmore/Bt/

Crowder DW, Carrière Y (2009) Comparing the refuge strategy for managing the evolution of insect resistance under different reproductive strategies. J Theor Biol 261:423-430

Crowder DW, Onstad DW (2005) Using a generational time-step model to simulate the dynamics of adaptation to transgenic corn and crop rotation by western corn rootworm (Coleoptera: Chrysomelidae). J Econ Entomol 98:518-533

Crowder DW, Onstad DW, Gray ME, Pierce CMF, Hagar AG, Ratcliffe ST, Steffey KL (2005) Analysis of the dynamics of adaptation to transgenic corn and crop rotation by western corn rootworm (Coleoptera: Chrysomelidae) using a daily time-step model. J Econ Entomol 98:534-551

Crowder DW, Onstad DW, Gray ME (2006) Planting transgenic insecticidal corn based on economic thresholds: consequences for integrated pest management and insect resistance management. J Econ Entomol 99:899-907

Devos Y, De Schrijver A, De Clercq P, Kiss J, Romeis J (2012) Bt-maize event MON 88017 expressing Cry3Bb1 does not cause harm to non-target organisms. Transgenic Res. doi: 10.1007/s11248-012-9617-z

Dun Z, Mitchell PD, Agosti M (2010) Estimating Diabrotica virgifera virgifera damage functions with field trial data: applying an unbalanced nested error component. J Appl Entomol 134:409-419 
EC (2012) Survey results for the presence of Diabrotica virgifera Le Conte in the European Union in 2011. Report from the Health and Consumers Directorate-General of the European Commission [Reference: Ares (2012) 56453208/05/2012]

EFSA (2011a) Guidance on the post-market environmental monitoring (PMEM) of genetically modified plants. EFSA J 2316:1-40. http://www.efsa.europa.eu/en/efsajournal/ doc/2316.pdf

EFSA (2011b) Scientific opinion on the annual post-market environmental monitoring (PMEM) report from Monsanto Europe SA on the cultivation of genetically modified maize MON810 in 2009. EFSA J 2376:1-66. http://www.efsa. europa.eu/en/efsajournal/doc/2376.pdf

EFSA (2011c) Scientific opinion on application (EFSA-GMOCZ-2008-54) for placing on the market of genetically modified insect resistant and herbicide tolerant maize MON 88017 for cultivation under regulation (EC) no. 1829/2003 from Monsanto. EFSA J 2428:1-152. http:// www.efsa.europa.eu/en/efsajournal/doc/2428.pdf

EFSA (2012) Scientific opinion on the annual post-market environmental monitoring (PMEM) report from Monsanto Europe SA on the cultivation of genetically modified maize MON810 in 2010. EFSA J 2610:1-35. http://www.efsa. europa.eu/en/efsajournal/doc/2610.pdf

El Khishen AA, Bohn MO, Prischmann-Voldseth DA, Dashiell KE, French BW, Hibbard BE (2009) Native resistance to western corn rootworm (Coleoptera: Chrysomelidae) larval feeding: characterisation and mechanisms. J Econ Entomol 102:2350-2359

Farinós GP, de la Poza M, Hernández-Crespo P, Ortego F, Castañera P (2004) Resistance monitoring of field populations of the corn borers Sesamia nonagrioides and Ostrinia nubilalis after 5 years of $B t$ maize cultivation in Spain. Entomol Exp Appl 110:23-30

Farinós GP, Andreadis SS, de la Poza M, Mironidis GK, Ortego F, Savopoulou-Soultani M, Castañera P (2011) Comparative assessment of the field-susceptibility of Sesamia nonagrioides to the Cry1 $\mathrm{Ab}$ toxin in areas with different adoption rates of $B t$ maize and in $B t$-free areas. Crop Prot 30:902-906

Farinós GP, de la Poza M, Ortego F, Castañera P (2012) Susceptibility to the Cry $1 \mathrm{~F}$ toxin of field populations of Sesamia nonagrioides (Lepidoptera: Noctuidae) in mediterranean maize cultivation regions. J Econ Entomol 105:214-221

FCEC (2009) Analysis of the economic, social and environmental impacts of options for the long-term EU strategy against Diabrotica virgifera virgifera (western corn rootworm), a regulated harmful organism of maize. http:// ec.europa.eu/food/plant/organisms/emergency/final_report_ Diabrotica_study.pdf

French BW, Bagley M, Nielson CN, Oswald K (2008) Fitness costs related to selection for resistance to the Cry $3 \mathrm{Bb} 1$ protein in a genetically diverse population of non-diapausing western corn rootworm. In: Entomological Society of America annual meeting, Reno, NV, USA, November 16-19, 2008

Gaspers C, Siegfried BD, Spencer T, Alves AP, Storer NP, Schuphan I, Eber S (2011) Susceptibility of European and North American populations of the European corn borer to the Cry1F insecticidal protein. J Appl Entomol 135:7-16
Gassmann AJ (2012) Field-evolved resistance to $B t$ maize by western corn rootworm: predictions from the laboratory and effects in the field. J Invertebr Pathol 110:287-293

Gassmann AJ, Hutchison WD (2012) Bt crops and insect pests: past successes, future challenges and opportunities. GM Crops Food Biotechnol Agric Food Chain 3:139

Gassmann AJ, Carrière Y, Tabashnik BE (2009) Fitness costs of insect resistance to Bacillus thuringiensis. Ann Rev Entomol 54:147-163

Gassmann AJ, Petzold-Maxwell JL, Keweshan RS, Dunbar MW (2011) Field-evolved resistance to $B t$ maize by western corn rootworm. PLoS One 6:e22629

Gassmann AJ, Petzold-Maxwell JL, Keweshan RS, Dunbar MW (2012) Western corn rootworm and Bt maize: challenges of pest resistance in the field. GM Crops Food Biotechnol Agric Food Chain 3:235-244

Glaser JA, Matten SR (2003) Sustainability of insect resistance management strategies for transgenic Bt corn. Biotechnol Adv 22:45-69

Glaum PR, Ives AR, Andow DA (2012) Contamination and management of resistance evolution to high-dose transgenic insecticidal crops. Theor Ecol 5:195-209

Goldstein JA, Mason CE, Pesek J (2010) Dispersal and movement behavior of neonate European corn borer (Lepidoptera: Crambidae) on non- $B t$ and transgenic $B t$ corn. J Econ Entomol 103:331-339

Gould F (1998) Sustainability of transgenic insecticidal cultivars: integrating pest genetics and ecology. Ann Rev Entomol 43:701-726

Gould F (2003) Bt-resistance management-theory meets data. Nat Biotechnol 21:1450-1451

Gould F, Cohen MB, Bentur JS, Kennedy GG, Van Duyn J (2006) Impact of small fitness costs on pest adaptation to crop varieties with multiple toxins: a heuristic model. J Econ Entomol 99:2091-2099

Gray ME (2011a) Severe root damage to $B t$ corn observed in northwestern Illinois. Bull 20. http://bulletin.ipm.illinois. edu/article.php?id=1555

Gray ME (2011b) Additional reports of severe rootworm damage to Bt corn received: questions and answers. Bull 22 . http://bulletin.ipm.illinois.edu/article.php?id=1569

Gray ME (2011c) Corn rootworm damage to $B t$ corn: should we expect more reports next year? Bull 24. http://bulletin. ipm.illinois.edu/article.php?id=1584

Gray ME, Steffey KL, Estes RE, Schroeder JB (2007) Responses of transgenic maize hybrids to variant western corn rootworm larval injury. J Appl Entomol 131:386-390

Gray ME, Sappington TW, Miller NJ, Moeser J, Bohn MO (2009) Adaptation and invasiveness of western corn rootworm: intensifying research on a worsening pest. Ann Rev Entomol 54:303-321

Hammack L, Ellsbury MM, Roehrdanz RL, Pikul JL Jr (2003) Larval sampling and instar determination in field populations of northern and western corn rootworm (Coleoptera: Chrysomelidae). J Econ Entomol 96:1153-1159

Head GP, Greenplate J (2012) The design and implementation of insect resistance management programs for $\mathrm{Bt}$ crops. GM Crops Food Biotechnol Agric Food Chain 3:144-153

Hemerik L, Busstra C, Mols P (2004) Predicting the temperature-dependent natural population expansion of the western 
corn rootworm, Diabrotica virgifera. Entomol Exp Appl 111:59-69

Hibbard BE, Duran PN, Ellersieck MR, Ellsbury MM (2003) Post-establishment movement of western corn rootworm larvae (Coleoptera: Chrysomelidae) in central Missouri corn. J Econ Entomol 96:599-608

Hibbard BE, Higdon ML, Duran DP, Schweikert YM, Ellersieck MR (2004) Role of egg density on establishment and plantto-plant movement by western corn rootworm larvae (Coleoptera: Chrysomelidae). J Econ Entomol 97:871-882

Hibbard BE, Vaughn TT, Oyediran IO, Clark TL, Ellersieck MR (2005) Effect of Cry3Bb1-expressing transgenic corn on plant-to-plant movement by western corn rootworm larvae (Coleoptera: Chrysomelidae). J Econ Entomol 98:11261138

Hibbard BE, El Khishen AA, Vaughn TT (2009) Impact of MON863 transgenic roots is equivalent on western corn rootworm larvae for a wide range of maize phenologies. J Econ Entomol 102:1607-1613

Hibbard BE, Meihls LN, Ellersieck MR, Onstad DW (2010a) Density-dependent and density-independent mortality of the western corn rootworm: impact on dose calculation of the rootworm-resistant Bt corn. J Econ Entomol 103:77-84

Hibbard BE, Clark TL, Ellersieck MR, Meihls LN, El Khishen AA, Kaster V, Steiner H-Y, Kurtz R (2010b) Mortality of western corn rootworm larvae on MIR604 transgenic maize roots: field survivorship has no significant impact on survivorship of F1 progeny on MIR604. J Econ Entomol 103:2187-2196

Hibbard BE, Frank DL, Kurtz R, Boudreau E, Ellersieck MR, Odhiambo JF (2011) Mortality impact of $B t$ transgenic maize roots expressing eCry3.1Ab, mCry $3 \mathrm{~A}$, and eCry3.1Ab plus mCry3A on western corn rootworm larvae in the field. J Econ Entomol 104:1584-1591

Huang F, Andow AA, Buschman LL (2011) Success of the highdose/refuge resistance management strategy after 15 years of $B t$ crop use in North America. Entomol Exp Appl 140:1-16

Hummel HE (2003) Introduction of Diabrotica virgifera virgifera into the Old World and its consequences: a recently acquired invasive alien pest species on Zea mays from North America. Commun Agric Appl Biol Sci 68:45-57

Hutchison W, Burkness E, Mitchell P, Moon R, Leslie T, Fleischer $\mathrm{S}$, Abrahamson M, Hamilton KL, Steffey KL, Gray ME, Hellmich RL, Kaster LV, Hunt TE, Wright RJ, Pecinovsky K, Rabaey TL, Flood RB, Raun ES (2010) Areawide suppression of European corn borer with $B t$ maize reaps savings to non- $B t$ maize growers. Science 330:222-225

Ives AR, Andow DA (2002) Evolution of resistance to Bt crops: directional selection in structured environments. Ecol Lett 5:792-801

Jaffe G (2009) Complacency on the farm: significant noncompliance with EPA's refuge requirements threatens the future effectiveness of genetically engineered pest-protected corn. Center for Science in the Public Interest. http://cspinet.org/new/pdf/complacencyonthefarm.pdf

Kang J, Krupke CH (2009a) Likelihood of multiple mating in Diabrotica virgifera virgifera (Coleoptera: Chrysomelidae). J Econ Entomol 102:2096-2100

Kang J, Krupke CH (2009b) Influence of weight of male and female western corn rootworm (Coleoptera:
Chrysomelidae) on mating behaviours. Ann Entomol Soc Am 102:326-332

Kim KS, Sappington TW (2005) Genetic structuring of western corn rootworm (Coleoptera: Chrysomelidae) populations in the United States based on microsatellite loci analysis. Environ Entomol 34:494-503

Kiss J, Edwards CR, Berger HK, Cata P, Cean M, Cheek S, Derron J, Festic H, Furlan L, Igrc-Barcic J, Ivanova I, Lammers W, Omelyuta V, Princzinger G, Reynaud P, Sivcec I, Sivicek P, Urek G, Vahala O (2005a) Monitoring of western corn rootworm (Diabrotica virgifera virgifera LeConte) in Europe 1992-2003. In: Vidal S, Kuhlmann U, Edwards CR (eds) Western corn rootworm: ecology and management. CABI, Wallingford, pp 29-39

Kiss J, Komáromi J, Bayar JK, Edwards CR, Hatala-Zsellér I (2005b) Western corn rootworm (Diabrotica virgifera virgifera LeConte) and the crop rotation systems in Europe. In: Vidal S, Kuhlmann U, Edwards CR (eds) Western corn rootworm: ecology and management. CABI, Wallingford, pp 189-220

Kruger M, Van Rensburg JBJ, Van den Berg J (2009) Perspective on the development of stem borer resistance to $B t$ maize and refuge compliance at the Vaalharts irrigation scheme in South Africa. Crop Prot 28:684-689

Kruger M, Van Rensburg JBJ, Van den Berg J (2011) Resistance to $B t$ maize in Busseola fusca (Lepidoptera: Noctuidae) from Vaalharts, South Africa. Environ Entomol 40: 477-483

Kruger M, Van Rensburg JBJ, Van den Berg J (2012) Transgenic $B t$ maize: farmers' perceptions, refuge compliance and reports of stem borer resistance in South Africa. J Appl Entomol 136:38-50

Krupke C, Marquardt P, Johnson W, Weller S, Conley SP (2009) Volunteer corn presents new challenges for insect resistance management. Agron J 101:797-799

Lefko SA, Nowatzki TM, Thompson SD, Binning RR, Pascual MA, Peters ML, Simbro EJ, Stanley BH (2008) Characterizing laboratory colonies of western corn rootworm (Coleoptera: Chrysomelidae) selected for survival on maize containing event DAS-59122-7. J Appl Entomol 132:189-204

Levine E, Oloumi-Sadeghi H (1991) Management of diabroticite rootworms in corn. Ann Rev Entomol 36:229-255

Levine E, Oloumi-Sadeghi H (1996) Western corn rootworm (Coleoptera: Chrysomelidae) larval injury to corn grown for seed production following soybeans grown for seed production. J Econ Entomol 89:1010-1016

Levine E, Spencer JL, Isard SA, Onstad DW, Gray ME (2002) Adaptation of the western corn rootworm to crop rotation: evolution of a new strain in response to a management practice. Am Entomol 48:94-107

Liu YB, Tabashnik BE (1997) Inheritance of resistance to Bacillus thuringiensis toxin Cry $1 \mathrm{C}$ in the diamondback moth. Appl Environ Entomol 63:2218-2223

Lu Y, Wu L, Jiang Y, Guo Y, Desneux N (2012) Widespread adoption of $B t$ cotton and insecticide decrease promotes biocontrol services. Nature. doi:10.1038/nature 11153

Ma BL, Meloche F, Wei L (2009) Agronomic assessment of Bt trait and seed or soil-applied insecticides on the control of corn rootworm and yield. Field Crop Res 111:189-196 
MacIntosh SC (2010) Managing the risk of insect resistance to transgenic insect control traits: practical approaches in local environments. Pest Manag Sci 66:100-106

Mallet J, Porter P (1992) Preventing insect adaptation to insectresistant crops: are seed mixtures or refugia the best strategy? Proc R Soc B Biol Sci 250:165-169

Marçon P, Young LJ, Steffey KL, Siegfried BD (1999) Baseline susceptibility of European corn borer (Lepidoptera: Crambidae) to Bacillus thuringiensis toxins. J Econ Entomol 92:279-285

Marquardt PT, Krupke CH (2009) Dispersal and mating behaviour of Diabrotica virgifera virgifera (Coleoptera: Chrysomelidae) in $B t$ cornfields. Environ Entomol 38:176-182

Marquardt PT, Krupke CH, Johnson WG (2012) Competition of transgenic volunteer corn with soybean and the effect on weed and insect resistance management. Weed Sci 60:193-198

Matten SR, Head GP, Quemada HD (2008) How governmental regulation can help or hinder the integration of Bt crops into IPM programs? In: Romeis J, Shelton AM, Kennedy GG (eds) Integration of insect-resistant genetically modified crops within IPM programs. Springer Science+Business Media BV, USA, pp 27-39

Meihls LN (2010) Development and characterization of resistance to transgenic corn in western corn rootworm. $\mathrm{PhD}$ dissertation, University of Missouri, p 111

Meihls LN, Higdon ML, Siegfried BD, Miller NJ, Sappington TW, Ellersieck MR, Spencer TA, Hibbard BE (2008) Increased survival of western corn rootworm on transgenic corn within three generations of on-plants greenhouse selection. Proc Natl Acad Sci USA 105:19177-19182

Meihls LN, Higdon ML, Ellersieck M, Hibbard BE (2011) Selection for resistance to $\mathrm{mCry} 3 \mathrm{~A}$-expressing transgenic corn in western corn rootworm. $\mathrm{J}$ Econ Entomol 104:1045-1054

Meinke LJ, Siegfried BD, Wright RJ, Chandler LD (1998) Adult susceptibility of Nebraska western corn rootworm (Coleoptera: Chrysomelidae) populations to selected insecticides. J Econ Entomol 91:594-600

Meinke LJ, Sappington TW, Onstad DW, Guillemaud T, Miller NJ, Komáromi J, Levay N, Furlan L, Kiss J, Toth F (2009) Western corn rootworm (Diabrotica virgifera virgifera LeConte) population dynamics. Agric For Entomol 11:29-46

Meissle M, Pilz C, Romeis J (2009) Susceptibility of Diabrotica virgifera virgifera (Coleoptera: Chrysomelidae) to the entomopathogenic fungus Metarhizium anisopliae when feeding on Bacillus thuringiensis Cry3Bb1-expressing maize. Appl Environ Microbiol 75:3937-3943

Meissle M, Mouron P, Musa T, Bigler F, Pons X, Vasileiadis VP, Otto S, Antichi D, Kiss J, Pálinkás Z, Dorner Z, van der Weide R, Groten J, Czembor E, Adamczyk J, Thibord JB, Melander B, Cordsen Nielsen G, Poulsen RT, Zimmermann O, Verschwele A, Oldenburg E (2010) Pests, pesticide use and alternative options in European maize production: current status and future prospects. J Appl Entomol 134:357-375

Meissle M, Hellmich RL, Romeis J (2011a) Impact of Cry3Bb1expressing Bt maize on adults of the western corn rootworm, Diabrotica virgifera virgifera (Coleoptera: Chrysomelidae). Pest Manag Sci 67:807-814
Meissle M, Romeis J, Bigler F (2011b) Bt maize and integrated pest management-a European perspective. Pest Manag Sci 67:1049-1058

Metcalf ER (1986) Foreword. In: Krysan JL, Miller TA (eds) Methods for the study of pest Diabrotica. Springer, New York

Miller N, Estoup A, Toepfer S, Bourguet D, Lapchin L, Derridj S, Kim KS, Reynaud P, Furlan L, Guillemaud T (2005) Multiple transatlantic introductions of the western corn rootworm. Science 310:992

Miller NJ, Guillemaud T, Giordano R, Siegfried BD, Gray ME, Meinke LJ, Sappington TW (2009) Genes, gene flow and adaptation of Diabrotica virgifera virgifera. Agric For Entomol 11:47-60

Moar W, Roush R, Shelton A, Ferré J, MacIntosh S, Leonard BR, Abel C (2008) Field-evolved resistance to Bt toxins. Nat Biotechnol 26:1072-1074

Moeser J, Vidal S (2005) Nutritional resources used by the invasive maize pest Diabrotica virgifera virgifera in its new South-east-European distribution range. Entomol Exp Appl 114:55-63

Monsanto (2009) Monsanto biotechnology trait acreage: fiscal years 1996 to 2009. http://www.monsanto.com/investors/ documents/2009/q4_biotech_acres.pdf

Murphy AF, Ginzel MD, Krupke CH (2010) Evaluating western corn rootworm (Coleoptera: Chrysomelidae) emergence and root damage in a seed mix refuge. J Econ Entomol 103:147-157

Murphy AF, Seiter NJ, Krupke CH (2011) The impact of Bt maize as a natal host on adult head capsule width in field populations of western corn rootworm. Entomol Exp Appl 139:8-16

Naranjo SE (1990) Comparative flight behavior of Diabrotica virgifera virgifera and Diabrotica barberi in the laboratory. Entomol Exp Appl 55:79-90

Naranjo SE (1991) Movement of corn rootworm beetles, Diabrotica spp. (Coleoptera: Chrysomelidae), at cornfield boundaries in relation to sex, reproductive status and crop phenology. Environ Entomol 20:230-240

Naranjo SE (1994) Flight orientation of Diabrotica virgifera virgifera and D. barberi (Coleoptera: Chrysomelidae) at habitat interfaces. Ann Entomol Soc Am 87:383-394

Nowatzki TJ, Bradley N, Warren KK, Putnam S, Meinke LJ, Gosselin DC, Harvey FE, Hunt TE, Siegfried B (2003) Infield labeling of western corn rootworm adults (Coleoptera: Chrysomelidae) with rubidium. J Econ Entomol 96: 1750-1759

Nowatzki TM, Zhou X, Meinke LJ, Vaughn T, Siegfried BD (2006) Effect of Bacillus thuringiensis Cry3Bb1 protein on the feeding behaviour and longevity of adult western corn rootworms (Coleoptera: Chrysomelidae). J Econ Entomol 99:927-930

Nowatzki TM, Lefko SA, Binning RR, Thompson SD, Spencer TA, Siegfried BD (2008) Validation of a novel resistance monitoring technique for corn rootworm (Coleoptera: Chrysomelidae) and event DAS-59122-7 maize. J Appl Entomol 132:177-188

OECD (2007) Consensus document on the safety information on transgenic plants expressing Bacillus thuringiensis-derived insect control proteins. In: Series on harmonisation of regulatory oversight in biotechnology [ENV/JM/MONO 
(2007)14], no. 42:1-10. http://www.oecd.org/dataoecd/36/ 61/46815888.pdf

Oleson JD, Park YL, Nowatzki TM, Tollefson JJ (2005) Nodeinjury scale to evaluate root injury by corn rootworms (Coleoptera: Chrysomelidae). J Econ Entomol 98:1-8

Olmer KJ, Hibbard BE (2008) The nutritive value of dying maize and Setaria faberi roots for western corn rootworm (Coleoptera: Chrysomelidae) development. J Econ Entomol 101:1547-1556

Onstad DW (2006) Modeling larval survival and movement to evaluate seed mixtures of transgenic corn for control of western corn rootworm (Coleoptera: Chrysomelidae). J Econ Entomol 99:1407-1414

Onstad DW (2008) Insect resistance management: biology, economics, and prediction. Academic Press, London

Onstad DW, Meinke LJ (2010) Modeling evolution of Diabrotica virgifera virgifera (Coleoptera: Chrysomelidae) to transgenic corn with two insecticidal traits. J Econ Entomol 103:849-860

Onstad DW, Joselyn M, Isard S, Levine E, Spencer J, Bledsoe L, Edwards C, Di Fonzo C, Wilson H (1999) Modeling the spread of western corn rootworm (Coleoptera: Chrysomelidae) populations adapting to soybean-corn rotation. Environ Entomol 28:188-194

Onstad DW, Guse CAG, Spencer JL, Levine E, Gray ME (2001a) Modeling the dynamics of adaptation to transgenic corn by western corn rootworm (Coleoptera: Chrysomelidae). J Econ Entomol 94:529-540

Onstad DW, Spencer JL, Guse CA, Levine E, Isard SA (2001b) Modeling evolution of behavioral resistance by an insect to crop rotation. Entomol Exp Appl 100:195-201

Onstad DW, Mitchell PD, Hurley TM, Lundgren JG, Porter RP, Krupke CH, Spencer JL, Difonzo CD, Baute TS, Hellmich RL, Buschman LL, Hutchison WD, Tooker JF (2011) Seeds of change: corn seed mixtures for resistance management and integrated pest management. J Econ Entomol 104:343-352

Oswald KJ, French BW, Nielson C, Bagley M (2011) Selection for Cry3Bb1 resistance in a genetically diverse population of nondiapausing western corn rootworm (Coleoptera: Chrysomelidae). J Econ Entomol 104:1038-1044

Oswald KJ, French BW, Nielson C, Bagley M (2012) Assessment of fitness costs in Cry3Bb1-resistant and susceptible western corn rootworm (Coleoptera: Chrysomelidae) laboratory colonies. J Appl Entomol. doi:10.1111/j.14390418.2012.01704.x

Oyediran IO, Hibbard BE, Clark TL (2004) Prairie grasses as alternate hosts of the western corn rootworm (Coleoptera: Chrysomelidae). Environ Entomol 33:740-747

Oyediran IO, Hibbard BE, Clark TL (2005) Western corn rootworm (Coleoptera: Chrysomelidae) beetle emergence from weedy Cry $3 B b 1$ rootworm-resistant transgenic maize. J Econ Entomol 98:1679-1684

Pan Z, Onstad DW, Nowatzki TM, Stanley BH, Meinke LJ, Flexner JL (2011) Western corn rootworm (Coleoptera: Chrysomelidae) dispersal and adaptation to single-toxin transgenic corn deployed with block or blended refuge. Environ Entomol 40:964-978

Petzold-Maxwell JL, Jaronski T, Gassmann AJ (2012a) Tritrophic interactions among $B t$ maize, an insect pest and entomopathogens: effects on development and survival of western corn rootworm. Ann Appl Biol 160:43-55

Petzold-Maxwell JL, Cibils-Stewart X, French BW, Gassmann AJ (2012b) Adaptation by western corn rootworm (Coleoptera: Chrysomelidae) to $B t$ maize: inheritance, fitness costs, and feeding preference. J Econ Entomol 104:1407-1418

Porter P, Cullen E, Sappington T, Schaafsma A, Pueppke S, Andow D, Bradshaw J, Buschman L, Cardoza YJ, DiFonzo C, French BW, Gassmann A, Gray ME, Hammond RB, Hibbard B, Krupke CH, Lundgren JG, Ostlie KR, Shields E, Spencer JL, Tooker JF, Youngman RR (2012) Letter from 22 members and participants of north central coordinating committee NCCC46 and other corn entomologists to EPA, March 5, 2012, http://www.organicconsumers. org/documents/Letter22Scientists.pdf

Qaim M (2009) The economics of genetically modified crops. Ann Rev Res Econ 1:665-694

Rangasamy M, Siegfried BD (2011) Validation of RNA interference in western corn rootworm Diabrotica virgifera virgifera LeConte (Coleoptera: Chrysomelidae) adults. Pest Manag Sci 68:587-591

Rausell C, García-Robles I, Sánchez J, Muñoz-Garay C, Martínez-Ramírez AC, Real MD, Bravo A (2004) Role of toxin activation on binding and pore formation activity of the Bacillus thuringiensis Cry3 toxins in membranes of Leptinotarsa decemlineata (Say). Biochim Biophys Acta 1660:99-105

Raybould A, Poppy GM (2012) Commercializing genetically modified crops under EU regulations-objectives and barriers. GM Crops Food Biotechnol Agric Food Chain 3:1-12

Raybould A, Stacey D, Vlachos D, Graser G, Li X, Joseph R (2007) Non-target organism risk assessment of MIR604 maize expressing mCry $3 \mathrm{~A}$ for control of corn rootworm. J Appl Entomol 131:391-399

Razze JM, Mason CE (2012) Dispersal behavior of neonate European corn borer (Lepidoptera: Crambidae) on $B t$ corn. J Econ Entomol 105:1214-1223

Roush RT (1994) Managing pests and their resistance to Bacillus thuringiensis: can transgenic crops be better than sprays? Biocontrol Sci Technol 4:501-516

Roush RT (1998) Two-toxin strategies for management of insecticidal transgenic crops: can pyramiding succeed where pesticide mixtures have not? Phil Trans R Soc Lond B Biol Sci 353:1777-1786

Saeglitz C, Bartsch D, Eber S, Gathmann A, Priesnitz KU, Schuphan I (2006) Monitoring the Cry1 Ab susceptibility of European corn borer in Germany. J Econ Entomol 99:1768-1773

Sanahuja G, Banakar R, Twyman RM, Capelle T, Christou P (2011) Bacillus thuringiensis: a century of research, development and commercial applications. Plant Biotechnol J 9:283-300

Schumann M, Vidal S (2012) Dispersal and spatial distribution of western corn rootworm larvae in relation to root phenology. Agric For Entomol. doi:10.1111/j.1461-9563. 2012.00573.x

Siegfried BD, Hellmich RL (2012) Understanding successful resistance management: the European corn borer and $\mathrm{Bt}$ corn in the United States. GM Crops Food Biotechnol Agric Food Chain 3:184-193 
Siegfried BD, Spencer T (2012) Bt resistance monitoring in European corn borer and western corn rootworms. In: Oliver M, Li Y (eds) Gene containment. Wiley, New York (in press)

Siegfried BD, Meinke LJ, Scharf ME (1998) Resistance management concerns for areawide management programs. J Agric Urban Entomol 15:359-369

Siegfried BD, Spencer T, Nearman J (2000) Baseline susceptibility of the corn earworm (Lepidoptera: Noctuidae) to the Cry1Ab toxin from Bacillus thuringiensis toxin. J Econ Entomol 93:1265-1268

Siegfried BD, Meinke LJ, Parimi S, Scharf ME, Nowatzki TJ, Zhou X, Chandler LD (2004) Monitoring western corn rootworm (Coleoptera: Chrysomelidae) susceptibility to carbaryl and cucurbitacin baits in the areawide management pilot program. J Econ Entomol 97:1726-1733

Siegfried BD, Vaughn TT, Spencer T (2005) Baseline susceptibility of western corn rootworm (Coleoptera: Chrysomelidae) to Cry3Bb1 Bacillus thuringiensis toxin. J Econ Entomol 98:1320-1324

Siegfried BD, Spencer T, Crespo AL, Storer NP, Head GP, Owens ED, Guyer D (2007) Ten years of Bt resistance monitoring in the European corn borer: what we know, what we don't know, and what we can do better? Am Entomol 53:208-214

Spencer JL, Mabry TR, Vaughn TT (2003) Use of transgenic plants to measure insect herbivore movement. J Econ Entomol 96:1738-1749

Spencer JL, Levine E, Isard SA, Mabry TR (2005) Movement, dispersal and behaviour of western corn rootworm adults in rotated maize and soybean fields. In: Vidal S, Kuhlmann U, Edwards CR (eds) Western corn rootworm: ecology and management. CABI, Wallingford, pp 121-144

Spencer JL, Hibbard BE, Moeser J, Onstad DW (2009) Behavior and ecology of the western corn rootworm (Diabrotica virgifera virgifera LeConte). Agric For Entomol 11:9-27

Storer NP (2003) A spatially explicit model simulating western corn rootworm (Coleoptera: Chrysomelidae) adaptation to insect-resistant maize. J Econ Entomol 96:1530-1547

Storer NP, Babcock JM, Edwards JM (2006) Field measures of western corn rootworm (Coleoptera: Chrysomelidae) mortality caused by Cry34/35Ab1 proteins expressed in maize event 59122 and implications for trait durability. J Econ Entomol 99:1381-1387

Storer NP, Babcock JM, Schlenz M, Meade T, Thompson GD, Bing JW, Huckaba RM (2010) Discovery and characterization of field resistance to Bt maize: Spodoptera frugiperla (Lepidoptera: Noctuidae) in Puerto Rico. J Econ Entomol 103:1031-1038

Storer NP, Kubiszak ME, King EJ, Thompson GD, Santos AC (2012a) Status of resistance to Bt maize in Spodoptera frugiperda: lessons from Puerto Rico. J Invertebr Pathol 110:294-300

Storer NP, Thompson GD, Head GP (2012b) Application of pyramided traits against Lepidoptera in insect resistance management for $B t$ crops. GM Crops Food Biotechnol Agric Food Chain 3:154-162

Szalai M, Köszegi J, Toepfer S, Kiss J (2011) Colonisation of first-year maize fields by western corn rootworm (Diabrotica virgifera virgifera) from adjacent infested maize fields. Acta Phytopathol Entomol Hun 46:215-226
Széll E, Zsellér I, Ripka G, Kiss J, Princzinger G (2005) Strategies for controlling western corn rootworm (Diabrotica virgifera virgifera). Acta Agron Hun 53:71-79

Tabashnik BE (1994) Delaying insect adaptation to transgenic plants: seed mixtures and refugia reconsidered. Proc R Soc B Biol Sci 255:7-12

Tabashnik BE (2008) Delaying insect resistance to transgenic crops. Proc Natl Acad Sci USA 105:19029-19030

Tabashnik BE, Gould F (2012) Delaying corn rootworm resistance to Bt corn. J Econ Entomol 105:767-776

Tabashnik BE, Gould F, Carrière Y (2004) Delaying evolution of insect resistance to transgenic crops by decreasing dominance and heritability. J Evol Biol 17:904-912

Tabashnik BE, Gassmann AJ, Crowder DW, Carrière Y (2008a) Insect resistance to $B t$ crops: evidence versus theory? Nat Biotechnol 26:199-202

Tabashnik BE, Gassmann AJ, Crowder DW, Carrière Y (2008b) Reply to Field-evolved resistance to $B t$ toxins. Nat Biotechnol 26:1074-1076

Tabashnik BE, Van Rensburg JBJ, Carrière Y (2009) Fieldevolved insect resistance to $B t$ crops: definition, theory and data. J Econ Entomol 102:2011-2025

Tinsley NA, Estes RE, Gray ME (2012) Validation of a nested error component model to estimate damage caused by corn rootworm larvae. J Appl Entomol. doi:10.1111/j.14390418.2012.01736.x

Toepfer S, Levay N, Kiss J (2006) Adult movements of newly introduced alien Diabrotica virgifera virgifera (Coleoptera: Chrysomelidae) from non-host habitats. Bull Entomol Res 96:327-335

Toepfer S, Peters A, Ehlers R-U, Kuhlmann U (2008) Comparative assessment of the efficacy of entomopathogenic nematodes species at reducing western corn rootworm larvae and root damage in maize. J Appl Entomol 132:337-348

Toepfer S, Haye T, Erlandson M, Goettel M, Lundgren JG, Kleespies RG, Weber DC, Walsh GC, Peters A, Ehlers R-U, Strasser H, Moore D, Keller S, Vidal S, Kuhlmann U (2009) A review of the natural enemies of beetles in the subtribe Diabroticina (Coleoptera: Chrysomelidae): implications for sustainable pest management. Biocontrol Sci Technol 19:1-65

Tuska T, Kiss J, Edwards CR, Szabó Z, Ondrusz I, Miskucza P, Garai A (2002) Determination of economic threshold for silk feeding by western corn rootworm (Diabrotica virgifera virgifera LeConte) adults in seed corn. Növényvédelem 38:505-511

Tyutyunov Y, Zhadanovskaya E, Bourguet D, Arditi R (2008) Landscape refuges delay resistance of the European corn borer to Bt-maize: a demo-genetic dynamic model. Theor Pop Biol 74:138-146

US EPA (2007) Biopesticides registration action document: modified Cry $3 \mathrm{~A}$ protein and the genetic material necessary for its production (via elements of pZM26) in event MIR604 corn SYN-IR604-8. http://www.epa.gov/oppbppd1/ biopesticides/ingredients/tech_docs/brad_006509.pdf

US EPA (2009a) Minutes of a scientific advisory panel held Feb. 23-24, 2009 on resistance risks of using a seed mix refuge with Pioneer's Optimum ${ }^{\circledR}$ AcreMax ${ }^{\mathrm{TM}} 1$ rootworm protected corn. http://www.epa.gov/scipoly/sap/meetings/ 2009/february/232009finalreport.pdf 
US EPA (2009b) Pesticide fact sheet. MON 89034, TC1507, MON 88017 and DAS-59122-7. http://www.epa.gov/ oppbppd1/biopesticides/pips/smartstax-factsheet.pdf

US EPA (2010a) Biopesticides registration action document: Bacillus thuringiensis $\mathrm{Cry} 3 \mathrm{Bb} 1$ protein and the genetic material necessary for its production (vector PVZMIR13L) in MON 863 corn (OECD unique identifier: MON-ØØ863-5) PC code: 006484 and Bacillus thuringiensis $\mathrm{Cry} 3 \mathrm{Bb} 1$ protein and the genetic material necessary for its production (vector PV-ZMIR39) in MON 88017 corn (OECD unique identifier: MON-88Ø17-3) PC code: 006498. http://www.epa.gov/oppbppd1/biopesticides/pips/ cry3bb1-brad.pdf

US EPA (2010b) Biopesticides registration action document: Bacillus thuringiensis Cry34Ab1 and Cry35Ab1 proteins and the genetic material necessary for their production (PHP17662 T-DNA) in event DAS-59122-7 corn (OECD unique identifier: DAS-59122-7), PC code: 006490. http://www.epa.gov/oppbppd1/biopesticides/pips/cry3435 ab1-brad.pdf

US EPA (2010c) Biopesticides registration action document: Optimum ${ }^{\circledR}$ AcreMax ${ }^{\mathrm{TM}}$ Bt corn seed blends. http://www. epa.gov/oppbppd1/biopesticides/pips/bt-seed-blends.pdf

US EPA (2011a) Updated BPPD IRM review of reports of unexpected Cry3Bb1 damage, Monsanto's 2009 corn rootworm monitoring report, and revised corn rootworm resistance monitoring plan for MON 88017, MON $88017 \times$ MON 810, MON 863, MON $863 \times$ MON 810, MON $89034 \times$ TC1507 $\times$ MON $88017 \times$ DAS-591227 , and MON $89034 \times$ MON 88017 (EPA reg. nos. $524-551,524-552,524-528,524-545$, and 68467-7); MRIDs 478846-01 and 478875-03. https://motherjones. com/files/epa-hq-opp-2011-0922-0003.pdf

US EPA (2011b) Biopesticides registration action document: MON $89034 \times$ TC1507 × MON $88017 \times$ DAS-59122-7 (SmartStax ${ }^{\circledR}$ ) Bt corn seed blend. http://www.epa.gov/ oppbppd1/biopesticides/pips/smartstax-seedblend.pdf

US EPA (2011c) Notice of pesticide registration 67979-17. Bt11 DAS-59122-7 MIR604 TCI507 corn. http://www.kellysolutions. com/erenewals/documentsubmit/KellyData\%5CGA\%5C pesticide\%5CMSDS\%5C67979\%5C67979-17\%5C6797917_BT11_X_DAS_59122_7_X_MIR604_X_TC1507_ CORN_ALTERNATE_BRAND_NAME_AGRISURE_ 3122_8_16_2011_11_10_07_AM.pdf

Vachon V, Laprade R, Schwartz JL (2012) Current models of the mode of action of Bacillus thuringiensis insecticidal crystal proteins: a critical review. J Invertebr Pathol 111:1-12

van Rensburg JBJ (2007) First report of field resistance by the stem borer, Busseola fusca (Fuller) to Bt-transgenic maize. S Afr J Plant Soil 24:147-151 van Rozen K, Ester A (2010) Chemical control of Diabrotica virgifera virgifera LeConte. J Appl Entomol 134:376-384

Vasileiadis VP, Sattin M, Otto S, Veres A, Pálinkás Z, Ban R, Pons X, Kudsk P, van der Weide R, Czembor E, Moonen AC, Kiss J (2011) Crop protection in European maizebased cropping systems: current practices and recommendations for innovative integrated pest management. Agric Syst 104:533-540

Vaughn T, Cavato T, Brar G, Coombe T, DeGooyer T, Ford S, Groth M, Howe A, Johnson S, Kolacz K, Pilcher C, Purcell J, Romano C, English L, Pershing J (2005) A method of controlling corn rootworm feeding using a Bacillus thuringiensis protein expressed in transgenic maize. Crop Sci 45:931-938

Walters FS, deFontes CM, Hart H, Warren GW, Chen JS (2010) Lepidopteran-active variable-region sequence imparts coleopteran activity in eCry3.1Ab, an engineered Bacillus thuringiensis hybrid insecticidal protein. Appl Environ Microbiol 76:3082-3088

Wan P, Huang Y, Tabashnik BE, Huang M, Wu K (2012) The halo effect: suppression of pink bollworm on non-Bt cotton by $B t$ cotton in China. PLoS One 7:e42004

Wesseler J, Fall EH (2010) Potential damage costs of Diabrotica virgifera virgifera infestation in Europe-the 'no control'. J Appl Entomol 134:385-394

Wilhelm R, Sanvido O, Castanera P, Schmidt K, Schiemann J (2010) Monitoring the commercial cultivation of $B t$ maize in Europe-conclusions and recommendations for future monitoring practice. Environ Biosaf Res 8:219-225

Wilson TA, Hibbard BE (2004) Host suitability of nonmaize agroecosystem grasses for the western corn rootworm (Coleoptera: Chrysomelidae). Environ Entomol 33:1102-1108

Wright RJ, Scharf ME, Meinke LJ, Zhou X, Siegfried BD, Chandler LD (2000) Larval susceptibility of an insecticideresistant western corn rootworm (Coleoptera: Chrysomelidae) population to soil insecticides: laboratory bioassays, assays of detoxication enzymes, and field performance. J Econ Entomol 93:7-13

Zhao JZ, Li YX, Collins HL, Shelton AM (2002) Examination of the $\mathrm{F}_{2}$ screen for rare resistance alleles to Bacillus thuringiensis toxins in the diamondback moth (Lepidoptera: Plutellidae). J Econ Entomol 95:14-21

Zhao JZ, Cao J, Collins HL, Bates SL, Roush RT, Earle ED, Shelton AM (2005) Concurrent use of transgenic plants expressing a single and two Bacillus thuringiensis genes speeds insect adaptation to pyramided plants. Proc Natl Acad Sci USA 102:8426-8430

Zukoff SN, Bailey W, Ellersieck MR, Hibbard BE (2012) Western corn rootworm larval movement in SmartStax seed blend scenarios. J Econ Entomol 104:1248-1260 